Cologne Business Working Papers

Cologne Business Discussion Papers

No. DP $11 / 1$

Cologne Business Studies

Wolfgang Veit

\title{
Competing approaches to measuring business regulation. Reducing Red Tape in Rwanda
}

\begin{abstract}
$\underline{\text { Abstract }}$
Country rankings with respect to a country's business environment draw strong international attention. Methods of business environment assessment differ, two competing methods will be described and compared with respect to their results for Rwanda in the years 2008-2010. They do not come to the same results regarding regulatory deficits and hence the demand for regulatory reform. When regulatory cost is considered, demand and supply of reforms are more in line than without cost considerations. The effectiveness of reforms undertaken in Rwanda varies. Based on interviews in late 2010, not all reforms were having the expected impact "on the ground".

JEL: K2,L5,R5
\end{abstract}

Fachhochschule Köln

Cologne University of Applied Sciences

Fakultät für Wirtschaftswissenschaften

Faculty for Economics and Business Administration 
Die Fakultät für Wirtschaftswissenschaften der Fachhochschule Köln trägt mit den Reihen Cologne Business Studies, Cologne Business Discussion Papers und Cologne Business Working Papers zum Diskurs mit Wissenschaft und Praxis bei.

- Die Cologne Business Studies leisten einen Beitrag zum Wissenstransfer zwischen Wissenschaft und Praxis. Sie beinhalten die Bearbeitung von wirtschaftlichen Praxisproblemen mit wissenschaftlichen Methoden.

- Die Cologne Business Discussion Papers sind die Plattform der Fakultät für den internen wissenschaftlichen Gedankenaustausch. Die Beiträge zu den internen Vortragsreihen werden in dieser Form veröffentlicht.

- In den Cologne Business Working Papers werden die Ergebnisse wirtschaftswissenschaftlicher Forschung an der Fachhochschule Köln einer breiteren Öffentlichkeit zur Verfügung gestellt.

Cologne University of Applied Sciences / Department of Economics and Business Administration contributes to academic exchange by means of three paper series: Cologne Business Studies, Cologne Business Discussion Papers and Cologne Business Working Papers

- Cologne Business Studies are a medium of the university's outreach activities. Here, research with particular relevance for business practice is being published.

- Cologne Business Discussion Papers are the department's platform for internal academic exchange. Also, contributions to the internal conference series are being published here.

- Cologne Business Working Papers represent the department's contributions to the wider scientific community.

Kontaktadresse / Contact:

Steffen Wolfer, M.A.

Fachhochschule Köln / Cologne University of Applied Sciences

Gustav Heinemann-Ufer 54, 50968 Köln

Email: steffen.wolfer@fh-koeln.de 


\section{List of abbreviations}

BMZ Bundesministerium für Wirtschaftiche Zusammenarbeit und Entwicklung

DB World Bank/IFC Doing Business Project

FDI Foreign Direct Investment

GTZ Gesellschaft für Technische Zusammenarbeit

IFC International Finance Corporation

IFS International Financial Statistics

IMF International Monetary Fund

MINICOM Ministry for Commerce, Government of Rwanda

OECD Organization for Economic Cooperation and Development

PSF $\quad$ Private Sector Federation of Rwanda

RDB Rwanda Development Board

RRA Rwanda Revenue Authority

RTR Cutting the cost of Red Tape main report

UNCTAD United Nations Conference on Trade and Development

WTO World Trade Organization 
Introduction

\subsection{Overview}

- "'Red Tape' is a short hand for unnecessary or excessively complicated regulations and inefficient administrative processes" (SBP,2008,9).

- "The expression 'red tape' refers to any unnecessary or redundant regulation that hinders productivity. (CFIB,2010,2)

Reduction of Red Tape is supposed to reduce business cost and therefore contribute to the level and growth GDP. It is a part of Good Governance ${ }^{1}$. The degree of Red Tape existing in a country's business environment is measured by a variety of measures and rankings. If positive, they are used by governments in their internal and external PR strategies.

The goal of this paper is to assess whether methods for evaluation of business regulatory environments paint a true picture of the regulatory regimes and thus contribute to Good Governance. The case analyzed here is Rwanda.

The first chapter briefly outlines the different methods of business environment analysis and the empirical evidence on the relevance of business environment reform for growth. The second chapter explores two competing concepts of business environment assessment in more depth: first, the SBP approach which is based on surveys of subjective perceptions of businesses, and second the World Bank's Doing Business (DB) Indicators which measure regulations as decreed by authorities. Both approaches will be compared with regard to

- Goals

- Method of gathering information

- Types of businesses considered

- Regional and sectoral scope

- Estimation of regulatory cost

- Ability to measure correctly supply of reforms be the government (DB) and demand for reforms by businesses (SBP)

- Effects on the government's reform agenda

The third chapter focuses on the results of both the DB and the SBP approach with regard to Rwanda. First, economic reforms as decreed by the Rwandan government will be described. This constitutes the supply side of business environment reforms. DB will then be analyzed regarding its accuracy of

\footnotetext{
1 The World bank conceives business environment regulation as one of 16 criteria for good
} governance. (World Bank, 2005,15) 
measuring the supply side. The results of the SBP exercise of 2008 represent the demand side ${ }^{2}$ for reforms. Demand and supply of reforms will then be compared in order to establish whether the Rwandan government by its policy met the demands of the business sector. Finally, the third chapter will compare the results of a survey of business environment conducted in 2010 with the assessment of the business environment by DB in the same year. This comparison is then used to evaluate whether the reforms undertaken in Rwanda between 2008 and 2010 have actually been effective and thus have contributed to the overall goal of Good Governance.

\subsection{Measures of Business Environment Quality}

The analysis of a country's business environment as performed by the World Bank's Doing Business (DB) Project has gained both increasing public and private attention. Latest results of this annual exercise have been widely published and commented (e.g. Economist, 2010,71-73); governments see the results as a measure of their reform efforts or use it as vehicle to initiate such reforms. Firms and investors in particular see it as a measure of the ease of doing business in a country. As a matter of fact, the DB's overall ranking of countries is called the "Ease of Doing Business Indicator".

Ever since its inception, the DB project has been receiving critical reviews. The World Bank Doing Business Webpage ${ }^{3}$ provides for a section listing major analytical work done with respect to the DB methodology. On top of that, Google Scholar lists over 1.5 million entries that relate to the DB project.

The methodology underlying $\mathrm{DB}$ is not undisputed and has led to internal evaluation of the project (IEG, 2008). Also, DB is not the only approach to measuring business environment. The World Bank undertakes two more projects (Investment Climate Index and Business Enterprise Surveys); outside the World Bank there are assessments provided by the World Economic Forum (Global Competitiveness Report), the UNCTAD (World Investment Report) and private sources like the Economist Intelligence Unit, to name a few. ${ }^{45}$

\footnotetext{
${ }^{2}$ For demand for institutional change: (Streeck/Thelen, 2005, pp2).

${ }^{3}$ http://www.doingbusiness.org/

${ }^{4}$ Comparative analyses of measures of business environment are numerous. Most of them focus on the different methods of calculating the cost of regulation to businesses. Also, most of them start from the factual regulation as determined by government decrees. Few, however, include in their analysis the subjective perception of business regulation within a wider framework of general market conditions. An exception is (FIAS,2009).

5 For a comparison of the World Bank's Doing Business approach and the Business Enterprise Survey approach see http://www.enterprisesurveys.org/Methodology/Compare.aspx
} 
These approaches complement the DB project; however, in 2008 an alternative to DB was initiated for Rwanda by the country's Private Sector Federation (PSF), the major Rwandan association of private firms ${ }^{6}$. The resulting report "Cutting the cost of Red Tape" (short: Red Tape Report, RTR) analyses areas of business environment similar to those of DB, but employs a different methodological approach (SBP, 2008). In view of the remarkable improvement of Rwanda's position in the DB rankings after publication of this report, the question arises whether the reforms are attributable to DB, RTR, or both. The underlying methodologies and their results will be compared.

Generally speaking, the RTR method of information gathering is perceptionbased, relying on a large number of respondents, whereas the DB method is mainly fact based, relying on a comparatively small number of respondents.

- RTR allows for the determination of regulatory cost by sector, firm size and region, whereas DB assumes a standard business case

- RTR is part of a comprehensive Public Private Dialogue, whereas DB is selectively including administration representatives.

The differences in quality and quantity of results of the competing approaches will be analyzed in this paper.

\section{Table 1: Assessing the business environment ${ }^{7}$}

\begin{tabular}{|l|l|l|}
\hline Type of analysis & Information provided by & Application \\
\hline Fact based analysis & Expert informants & DB \\
\hline Evidence/perception based & Firms, management & Regulatory Review (RTR) \\
\hline $\begin{array}{l}\text { Procedural audit, based on } \\
\text { time and motion study }\end{array}$ & $\begin{array}{l}\text { Government agencies and } \\
\text { their clients }\end{array}$ & $\begin{array}{l}\text { Ex post evaluation of } \\
\text { regulations / DB / RTR }\end{array}$ \\
\hline $\begin{array}{l}\text { Regulatory Impact Analysis } \\
\text { (RIA) }\end{array}$ & Affected stakeholder groups & $\begin{array}{l}\text { Ex ante evaluation of } \\
\text { regulations }\end{array}$ \\
\hline
\end{tabular}

\subsection{The regulation - growth connex}

6 This report is one of the results of the project "Promotion of the economy and employment" commissioned by the German Federal Ministry for Economic Cooperation and Development (BMZ) and co-funded by the Royal Netherlands Embassy to Rwanda; the project duration is from 2004 to 2013. GTZ on behalf of BMZ implements this project, which, apart from the so-called Red Tape analysis consists of further instruments (e.g. business and investment climate surveys, Regulatory Impact Assessment) to strengthen the private sector and improve the business environment in Rwanda.

${ }^{7}$ For a more detailed description of the types of analysis see (SBP,2008,15)

${ }^{8}$ Ex ante evaluation / RIA is part of the GTZ project, but not subject of discussion here 
In order to assess the relevance of business environment studies, the role of the business environment for growth and investment has to be analyzed.

For both, RTR and DB, the term "business environment" is defined as the set of regulations governing private sector activity. The rationale behind business environment analysis is that less cumbersome regulation will enhance growth of firms and employment (IEG, 2008,3). In other words, regulation, directly, though not solely, affects investment climate and investment activity and therefore growth $^{9}$ (Figure 1). While most analyzes find a positive correlation between the quality of regulation and growth, the direction of causality is not clear. Also, it is not quite clear whether business regulation as measured by the DB indicators is strongly correlated with both factual regulation as it affects businesses and economic outcomes (Commander, Svejnar, 2007).

\section{Figure 1: The Regulation - Growth connex}

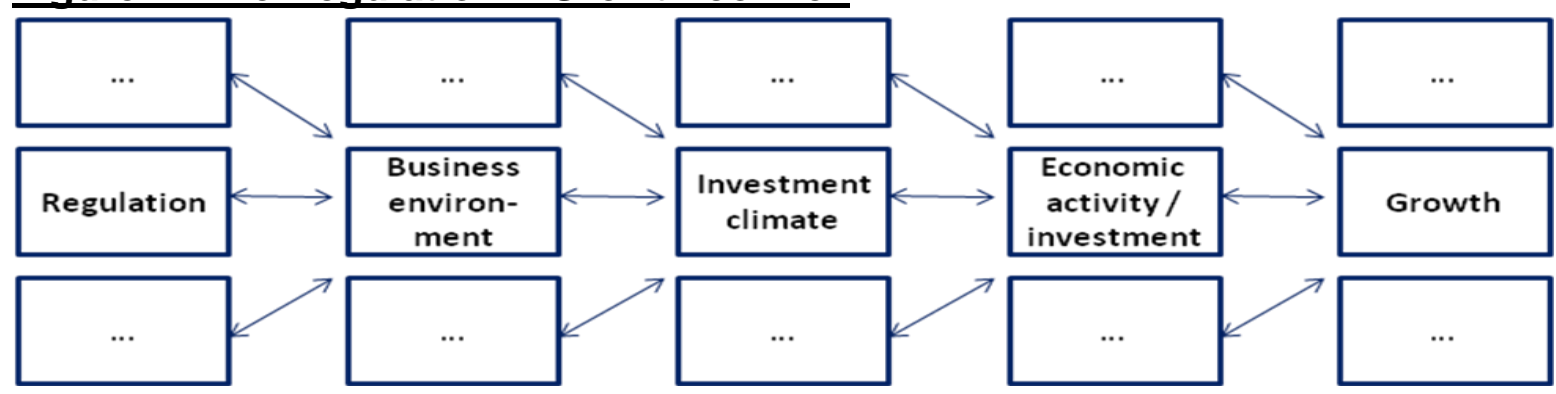

Investment climate can be differenciated into the following areas: Stability and Security, Regulation and Taxation, Finance and Infrastructure, and Employment and Labour markets (IEG,2008,4). Table 2 further differentiates these areas and highlights the subareas covered by DB in the shaded areas. The RTR approach is potentially open to all of the below mentioned areas.

Research on the DB methodology shows that there the fact based and the (few) perception based indicators are highly correlated with other measures of investment climate like the Global Competitiveness Index (World Development Forum) and the Business Environment Rankings (Economist Intelligence Unit). However, there is a weaker correlation of perception-based indicators with the DB indicators in middle and lower income countries (IEG,2008,81, FN 4; DB11, 2010,13)). This is of interest in the Rwandan case.

\footnotetext{
${ }^{9}$ a fundamental paper on the issue is: Djankov, et al, 2000; Djankov et al, 2006; for an analysis based on firm data in Bangladesh, India, China and Pakistan see: Dollar et al, 2003, 29; for a larger set of industrialized and developing countries, see Ciccone, 2007, 17; for OECD countries see Alesina et al., 2005, 21
} 
2: Elements of investment climate ${ }^{10}$

\begin{tabular}{|c|c|c|}
\hline $\begin{array}{l}\text { Stability and } \\
\text { Security }\end{array}$ & $\begin{array}{l}\text { Stability } \\
\text { - Reduce political instability from civil wars, } \\
\text { political conflict, etc. } \\
\text { - Maintain macro-economic stability with low } \\
\text { inflation, sustainable budget deficits, and } \\
\text { realistic exchange rates }\end{array}$ & $\begin{array}{l}\text { Security of property rights } \\
\text { - Reduce robbery, fraud, and other crimes } \\
\text { against property } \\
\text { - End uncompensated expropriation of } \\
\text { property } \\
\text { - Verify rights to land and other Property } \\
\text { - Facilitate contract enforcement }\end{array}$ \\
\hline $\begin{array}{l}\text { Regulation and } \\
\text { Taxation }\end{array}$ & $\begin{array}{l}\text { Regulation } \\
\text { - Balance market and government failures for a } \\
\text { good institutional fit } \\
\text { - Address regulatory cost and informality } \\
\text { - Reduce uncertainty and risk in interpretation } \\
\text { and implementation of existing regulations } \\
\text { - Reduce regulatory barriers to competition }\end{array}$ & $\begin{array}{l}\text { Taxation } \\
\text { - Broaden tax base Increase autonomy of tax } \\
\text { agencies } \\
\text { - Reduce corruption in tax administration } \\
\text { - Confront informality } \\
\text { - Simplify tax structure } \\
\text { - Improve customs administration } \\
\text { - Improve compliance through computerization }\end{array}$ \\
\hline $\begin{array}{l}\text { Finance and } \\
\text { Infrastructure }\end{array}$ & $\begin{array}{l}\text { Finance } \\
\text { - Foster competition in the banking sector } \\
\text { - Control risk-taking by banks and other } \\
\text { financial institutions } \\
\text { - Secure rights of borrowers, creditors, and } \\
\text { shareholders } \\
\text { - Improve credit information by using credit } \\
\text { bureaus and stronger data protection and } \\
\text { credit reporting laws }\end{array}$ & $\begin{array}{l}\text { Infrastructure } \\
\text { - Improve climate for investment in } \\
\text { infrastructure by securing investors' property } \\
\text { rights, } \\
\text { fostering competition, and } \\
\text { encouraging private participation } \\
\text { - Improve public management of } \\
\text { infrastructure }\end{array}$ \\
\hline $\begin{array}{l}\text { Employment } \\
\text { and labour } \\
\text { markets }\end{array}$ & $\begin{array}{l}\text { Labour Market } \\
\text { - Foster a skilled and healthy workforce by } \\
\text { expanding access to education, improving } \\
\text { education quality, supporting life-long learning, } \\
\text { and the like } \\
\text { - Help workers affected by large scale } \\
\text { restructurings by reinforcing social insurance } \\
\text { mechanisms and reaching out to the large } \\
\text { share of workers in rural and informal } \\
\text { economies } \\
\text { - Craft labor market interventions to benefit all } \\
\text { (formal and informal) in the process of setting } \\
\text { wages, regulation of working conditions, and } \\
\text { hiring and firing of workers }\end{array}$ & \\
\hline $\begin{array}{l}\text { Source: adapted from } \\
\text { (IEG, 2008, 4) }\end{array}$ & & \\
\hline
\end{tabular}

On a more disaggregated basis, of the above mentioned DB-related regulatory areas relevant for investment climate, none proved to be significantly correlated with growth, investment and employment (IEG, 2008, 36),(Eiffert,2007, 37). As the DB overall rankings are positively correlated with other investment climate measures, this raises the question to which extent the latter provide significant information about actual business activity and the associated macro variables.

Some business surveys on the effect of regulation on productivity and investment, however, suggest a causal relationship between regulation and investment (CFIB, 2010,9-10).

All in all, no clear causal relationship between the measures of business environment and investment/growth is to be found in the literature.

\footnotetext{
${ }^{10}$ Shaded areas indicate types of regulation covered by DB
} 


\section{Methodological underpinnings of SBP and DB}

The approaches to business environment measurement adopted by SBP and DB are part of a larger set of methods that are used to assess regulation either ex ante or ex post. In the following sections both approaches will be introduced, and their distinguishing features with regard to their results will be highlighted.

\subsection{The SBP Approach ${ }^{11}$}

SBP's RTR is based on the "regulatory review methodology", which "encompasses the assessment of regulatory costs, and the identification of key administrative blockages and delays that contribute to these cost" (SBP,2008,14). RTR is based on a survey of businesses, and is therefore of a perception based type $^{12}$. However, as the methodology gathers data on the real cost of compliance (cash flow, management time, and other internal resources) with existing regulations, it provides factual information, too. Over and above this, the aim of the RTR methodology is to provide information to governments on the specific hurdles faced by firms, allowing a government to fine tune further reform.

The RTR design of a survey is country specific. The companies surveyed are selected to create a representative sample of the formal business sector, with respect to industry, size, and regional distribution ${ }^{13}$. However, SBP cooperates closely with national business organizations. It is not clear whether membership in these organizations and cooperation with the survey team are voluntary, and whether this may result in a bias.

The areas covered by RTR were not pre-defined by a questionnaire or by SBP. Instead, RTR aims to cover a range of relevant regulatory hurdles as wide as possible. As these hurdles - and their perceptions - differ from country to country, this approach is not a priori open to international comparisons. Rather, an economy specific regulatory landscape is being created. In the case of Rwanda, only three significant areas of regulatory burdens emerged from the open questions asked: taxation, trade and labor regulations. Thus, the actual coverage of RTR may seem to be more narrow, and as a matter of fact is more narrow in

\footnotetext{
${ }^{11}$ Based on the below described SBP approach, an analysis of the Rwandan business environment was performed and published in a report titled "Cutting the Cost of Red Tape" (in short:RTR). As the methodology is country specific, all descriptions of the SBP approach will refer to RTR

${ }_{12}$ Perception based surveys are subjective by nature. Few surveys of business regulation include the subjective assessment of business regulation; a comparison of cost measurement methods used internationally, compiled by Bertelsmann Stiftung, identified two out of seven methods to include subjective assessments (Riedel,2009,29)

${ }^{13}$ In the Rwandan case, 276 large/medium and 127 small enterprises in all provinces and from all sectors of the economy were selected for the sample (SBP,2008,124).
} 
the case of Rwanda, than that of $\mathrm{DB}$, but it reflects the relative weight managers put on the different regulatory areas, and the relative weight of regulation vis-à-vis other policy areas (e.g. education, infrastructure, etc). RTR also allows to distinguish between government regulations and other hurdles faced by firms, putting into perspective the role of government ${ }^{14} 15$.

RTR does not use a standardized business case to define a typical firm. Instead, it allows for differentiation by geographical area, firm size, industry and other dimensions. This of course puts additional weight on the selection process in order to avoid bias with respect to one of the above dimensions ${ }^{16}$.

The sequence of questions raised runs from most general to most specific. First, factors generally discouraging business growth, employment, investment or any other area of concern are asked and ranked, yielding a distinction between regulatory and non-regulatory factors (such as competitive situation, business cycle, infrastructure etc (SBP,2008,21,42). This is followed by questions about specific regulatory hurdles which allow to distinguish among the government agencies involved in the respective areas of concern.

In a further step, the cost of regulations identified as major hurdles is assessed. RTR distinguishes between compliance cost, administrative cost, efficiency cost, and non-compliance cost (RTR, 2008,28):

\section{Table 3: Requlatory cost categories}

\begin{tabular}{|l|l|l|}
\hline Category of regulatory cost & $\begin{array}{l}\text { Examples of Activities } \\
\text { involved }\end{array}$ & Burden on... \\
\hline Compliance Cost & $\begin{array}{l}\text { Time; fees to service } \\
\text { providers }\end{array}$ & Firms; economy \\
\hline $\begin{array}{l}\text { Efficiency and opportunity } \\
\text { cost }\end{array}$ & $\begin{array}{l}\text { Reduced business activity } \\
\text { or size }\end{array}$ & Economy \\
\hline Non-compliance cost & $\begin{array}{l}\text { Paying fines, bribes } \\
\text { economy }\end{array}$ \\
\hline Administrative cost & $\begin{array}{l}\text { Government agency } \\
\text { activities }\end{array}$ & Economy \\
\hline Source: adapted from (SBP,2008,28) & & \\
\hline
\end{tabular}

Of these cost categories, compliance cost is analyzed within the RTR framework. Other cost categories, and efficiency cost in particular, can be assessed indirectly by asking about the ways businesses try to avoid regulatory cost (e.g. outsourcing

\footnotetext{
${ }^{14}$ SBP, 2008, 21

${ }^{15}$ In other words, the wide scope suggested by the DB method may overemphasize areas that are not actually seen as problematic by actors on the ground.

${ }^{16}$ For the sample design of RTR, see section 3.4
} 
or limiting the firms size in order not to cross certain thresholds may increase inefficiency cost (SBP,2008,51)) ${ }^{17}$.

\subsection{The Doing Business Approach}

The World Bank's Doing Business approach goes back to the year 2004 when the first annual report was published. It attempts to gather information on nine indicators that are supposed to describe regulations governing the typical life cycle of a firm, from starting to closing a firm. Annex 1 lists these indicators and the associated sub-indicators ${ }^{18}$. It should be noted that this list reflects the assessment of regulations as performed in the 2011 annual report. Prior to that date, an indicator set covering labor relations was included; this, together with information on electricity supply, is now presented in an annex to the annual report (from the 2011 on), but not included in the overall DB rankings.

Data on the sub-indicators are provided by selected experts in the field, so called informants. These, in the case of the DB 11 report, consist of "more than 8,200 local experts, including lawyers, business consultants, accountants, freight forwarders, government officials and other professionals routinely administering or advising on legal and regulatory requirements" (DB11,2010,109). However, as DB counts each completed questionnaire as one informant (IEG;2008,13), the actual number of experts may be considerably smaller. During the 2008 evaluation exercise the actual average number of questionnaire informants per indicator set ranged from 1 to 3.5. In other words, the average number of informants per country, looking at all nine indicator sets, was 9.5 persons in 2008 . This number included lawyers (70\%), government officials (18\%), Accountants (8\%), and other experts (4\%), but no managers of firms conforming with the standard business case (see below) ${ }^{19}$.

DB data contain two types of information: first, factual information about existing laws and regulations, and second, time and motion information about the cost of obtaining clearances from authorities. However, the latter type of data are not recorded at the firm level, but at the agent/informant level and they reflect official fee schedules (DB11,2010,12), not necessarily the actual cost of obtaining clearances.

\footnotetext{
${ }^{17}$ For the underlying methodology of cost calculation see (SBP,2008,62).

${ }^{18}$ The set of indicators has been changing over time. Therefore, a comparison of data over time has limitations. For a definition of the indicators valid in a particular year, see the respective annual reports of the DB project. The database provided online does include adjusted values for indicators, but still does not calculate rankings reaching back more than two years.

${ }^{19}$ DB 2009 lists 22 persons for Rwanda, of which two were positively identified as belonging to a (the same) business (freight service) (World Bank,2009,184)
} 
Informants are assuming a standard business case when evaluating the relevant regulations. These assumptions are listed in Annex 3.

A special feature of $D B$ is the ranking of countries along their performance with respect to individual indicator sets and, on this basis, along an overall "Ease of Dong Business" performance. The method raises a number of important issues which deserve attention. However, as they are beyond the scope of this paper they will not be dealt with here.

\subsection{Comparison of the two approaches}

Both, the SBP and the DB approach to measuring business environment regulation will be compared with regard to the criteria mentioned in section 1.1.

- Goals: Both the RTR and the DB approach take measure of a country's business environment. Their stated goals are similar: to provide governments with a regulatory profile that allows the identification of hurdles and bottlenecks and to initiate reform efforts.

- Method of gathering information: DB applies a so called "fact based" method, i.e. firms agents and officials dealing with regulation as it is written down in laws and decrees is evaluated; also, DB relies on a small number of informants (on average less than 10 per country). SBP follows a so called perception based method, i.e. it surveys firms directly with regard to how regulation - whether decreed or not - affects businesses on the ground. The number of firms is large and structured enough to allow a sample representative of the country's economic structure. Also, RTR focuses strongly on the cost of regulatory burdens; DB does not allow the calculation of aggregated regulatory cost. DB only counts the cost that is based on official fee schedules; the cost of compliance with the regulation is only partially covered where time is used as a measure of regulatory compliance. However, as noted above, compliance in DB is seen as activities performed by agents acting on behalf of firms, not as actions of firm staff themselves. It is not clear, whether this, apart from the type of firm definition of the standard business case, creates a further bias towards larger firms which can afford to hire these agents. Small firms, and those in transition from the informal sector into the formal sector in particular, are less likely to hire agents. The effect of regulation on this class of firms therefore is likely not to be covered by the DB analysis; this being in contradiction to the original DB goals which emphasize the transition of informal businesses into the formal sphere as a major driver of (official) employment, growth and investment. Data obtained through either method are subject to cleaning and validation processes. These are not fully 
transparent; they tend to allow for biases especially where a high share of questions are open, as is the case with the RTR.

- Types of businesses considered: DB assumes a standard business case for all countries, whereas SBP surveys a sample of firms typical for the country concerned. DB allows a cross country comparison of results. SBP's results are country specific.

- Regional and sectoral scope: DB generally focuses on a country's capital city, but allows for separate studies of other regions or industry clusters within a country; sectors are not specified. SBP considers a country's regions and sectors as they are representative of the country's economic structure.

- Estimation of regulatory cost: DB lists cost as listed in official fee schedules. SPB estimates the total cost of compliance with regulations at the firm, regional, sectoral, and macro level.

- Ability to measure correctly supply of regulatory reforms by the government (DB) and demand for reforms by businesses (SBP): DB measures reforms as they are decreed. This should allow for a correct description of a governments reform efforts when communication with the authorities is working. SBP cannot measure supply of reforms, but rather forms a basis for demand of reforms as firms are listing the major hurdles to doing business. The adequacy of the demand estimation relies heavily on the quality of data generation.

- Effects on government reform agenda: The approaches differ in their effects: whereas the SBP approach - due to its country specific nature - is not easily open to cross country comparisons, the DB approach is best known for its country rankings. On the other hand, the RTR approach allows governments to target regulatory reform in such a way as to relieve firms from the most cumbersome and costly regulators burdens. DB is less well suited to yield this result, because the measured business environment reflects laws as they are written rather than their enforcement and effect on businesses "on the ground" (see for this distinction: La Porta et al, 2008, 293).

\section{Case study Rwanda}

This chapter focuses on the results of both the DB and the SBP approach with regard to Rwanda. First, economic reforms as decreed by the Rwandan government will be described. This constitutes the supply side of business environment reforms. DB will then be analyzed regarding its accuracy of measuring the supply side. The results of the SBP approach of 2008 are interpreted as a measure of the demand side. Demand and supply of reforms will then be compared in order to establish whether the Rwandan government by its policy met the demands of the business sector. Finally, the third chapter will compare the results of a survey of business environment conducted in 2010 with 
the assessment of the business environment by DB in the same year. This comparison is then used to evaluate whether the reforms undertaken in Rwanda between 2008 and 2010 have actually been effective and thus have contributed to the overall goal of Good Governance.

\subsection{Economic environment and economic reforms in Rwanda}

First, the major sources of information on the business environment in Rwanda will be sketched. This is followed by an overview of reforms in Rwanda since 2007 as stated by the Rwandan government.

Major sources of information about the Rwandan regulatory environment are the Rwanda government and the World Bank. The World Bank mostly lists reforms documented in its DB Database. Other sources of information on the reform efforts of the Rwandan government are scarce and scattered, sometimes only indicative of reforms. The latest WTO Trade Policy Review dates from 2004 and therefore does not include the period of reforms. The IMF commends Rwanda's successful macroeconomic adjustment. In June 2010, Rwanda adopted the IMF's PSI program (Policy Support Instrument) which is open to countries that do not depend on financial assistance from the IMF anymore (Gershenson,2010). IMF International Financial Statistics (IFS) at the time of writing do not offer relevant data beyond 2008. UNCTAD data show that between 2007 and 2009 Rwanda recorded an annual increase in FDI inflows of $20 \%$ (UNCTAD, 2010, 168); its FDI stock rose fivefold in each of the decades 1990-2000 and 2000-2010 (UNCTAD,2010,173). ${ }^{20}$

Reforms of the business environment regulation undertaken in Rwanda as stated by the government are summarized in table 4b. Over the period 2007 to 2010 a total of 21 reforms were implemented. In terms of the DB indicator categories, the largest number of them focused on taxes, trade, and property registration. Most of the reforms occurred in the year 2009/2010.

\footnotetext{
${ }^{20}$ It is interesting to note that although within an international country ranking of FDI inflows Rwanda jumped from rank 105 to rank 65 in only two years, the FDI inward potential index for Rwanda barely changed between 2007 and 2008 (UNCTAD, 20102,2). It would be interesting to see whether economic reforms after 2008 will have an impact on this outcome-oriented indicator.
} 
3.2. Registration and timing of reforms by the World Bank Doing Business Database

In this section, the sequence of business environment changes as identified by DB will be compared with those reported by the Rwandan government in order to evaluate the accuracy of reform measurement by DB.

Figures $2-9$ illustrate the timing of regulatory reforms in Rwanda. The graphs are based on data reported in the DB annual reports ${ }^{21}$ They show the development of DB sub-indicators of business regulation by means of index values. The base of these values is 1 for the year the sub indicator was first observed by DB. It becomes clear that most of the economic reforms in Rwanda recorded by DB occurred in 2008 or in the following years. These data confirm the description of reforms by the government and international organizations, (the sources presented in section 3.1). It is confirmed, too, by tables $4 \mathrm{a}$ and $4 \mathrm{~b}$ which list reform activities as reported indirectly by DB and directly by the Rwandan government.

\section{Figures 2 to 9: Timing of reforms in Rwanda}

Fig. 2: Rwanda: starting a business

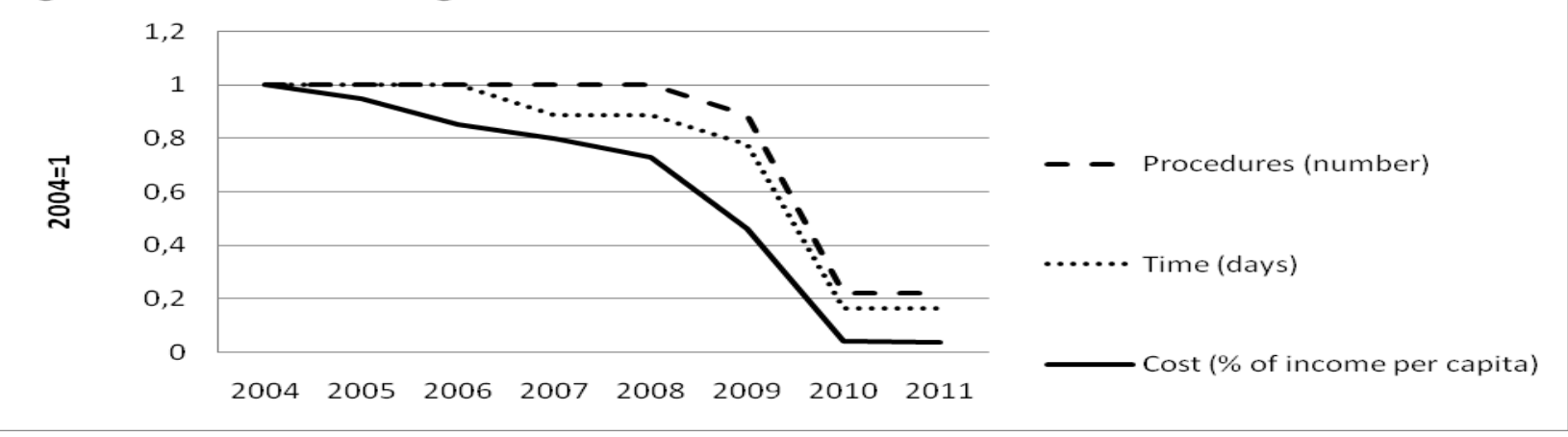

Fig. 3: Rwanda: dealing with construction permits

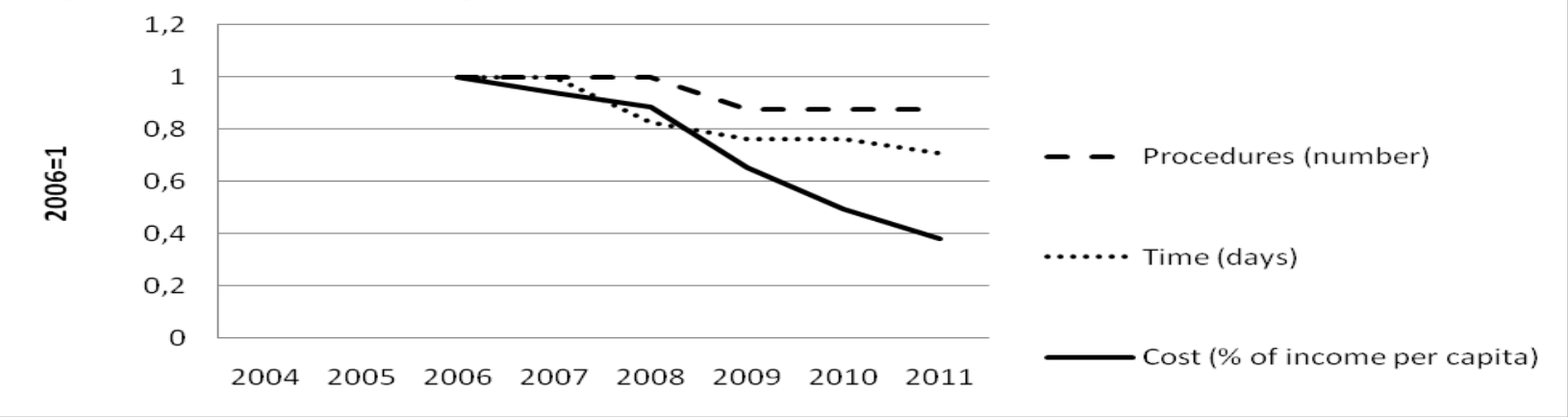

${ }^{21}$ The years in Figures 1-9 are years of DB annual reports, not years of reforms 
Fig 4: Rwanda: registering property

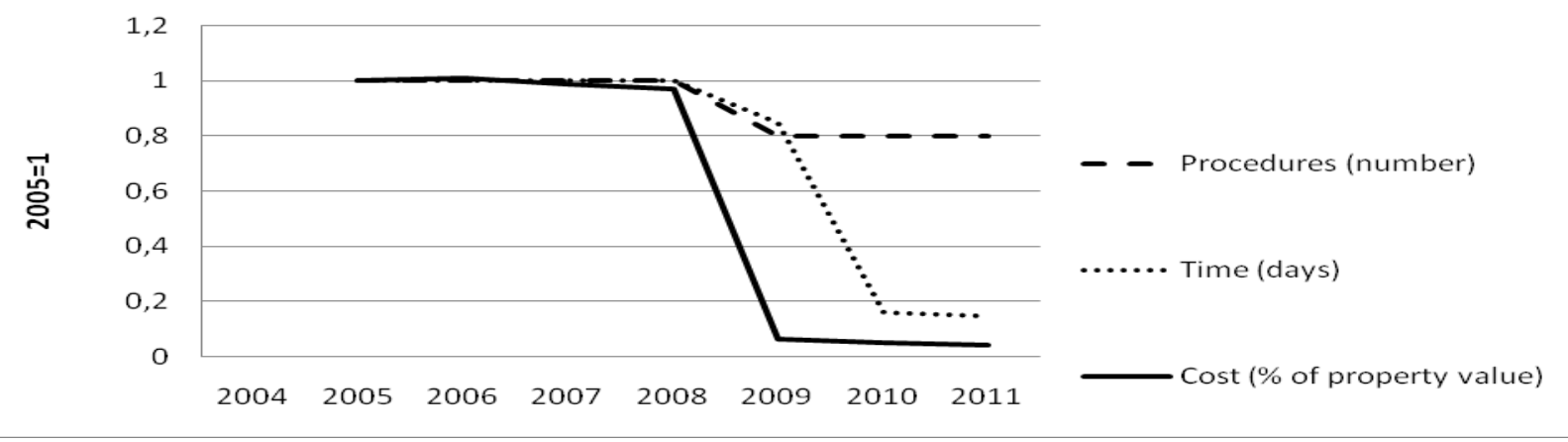

Fig 5:Rwanda: getting credit

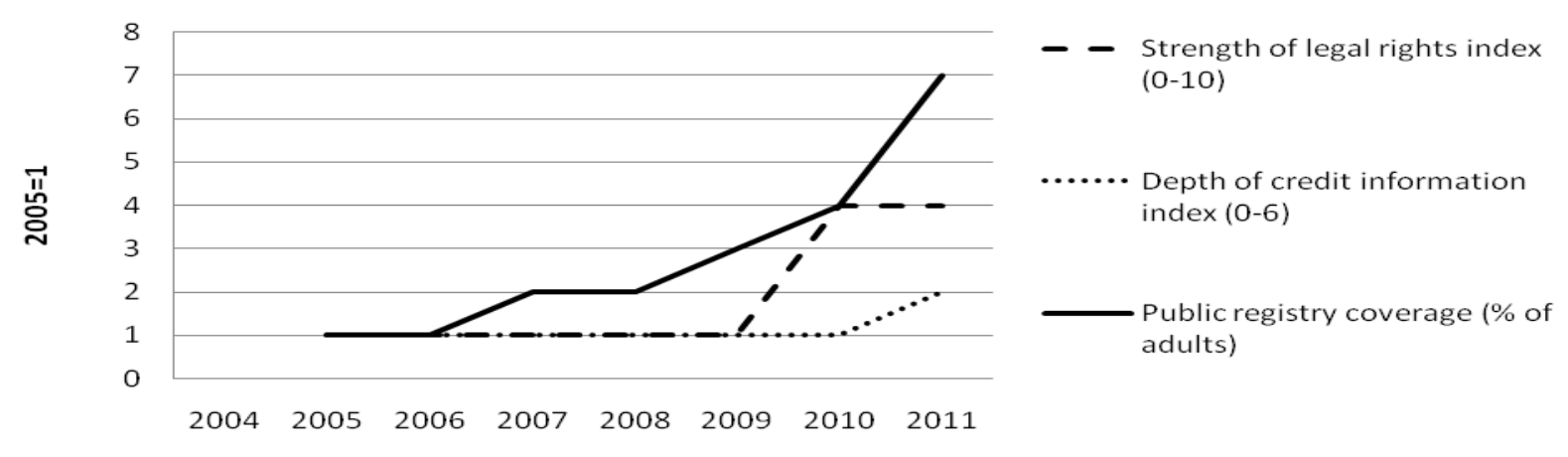

Fig 6: Rwanda: protecting investors
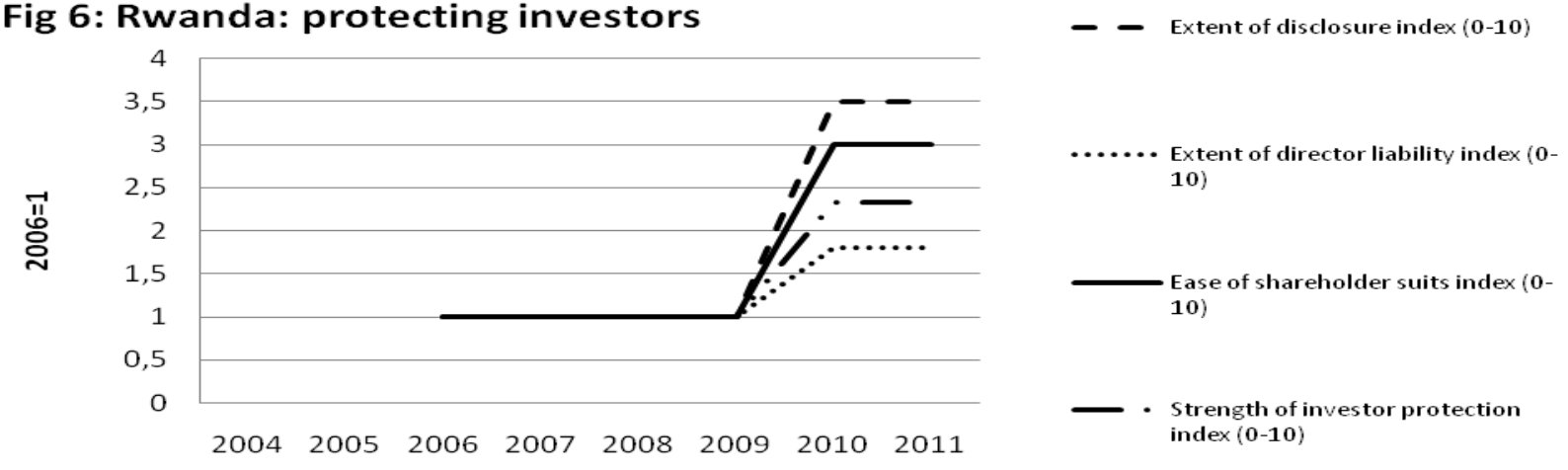

Fig 7: Rwanda: paying taxes

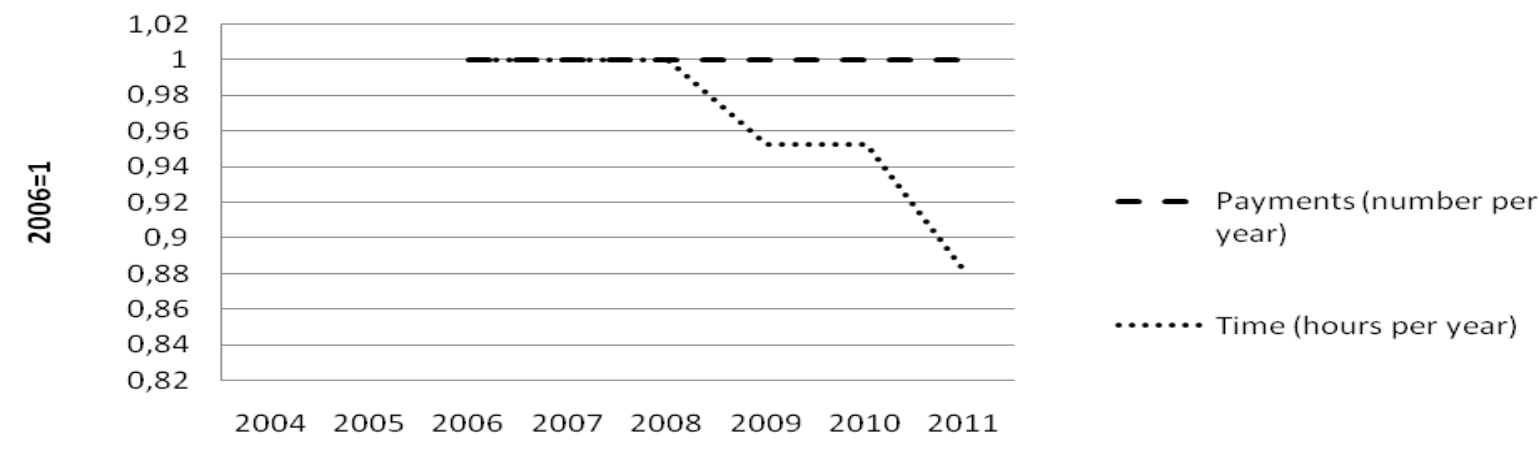




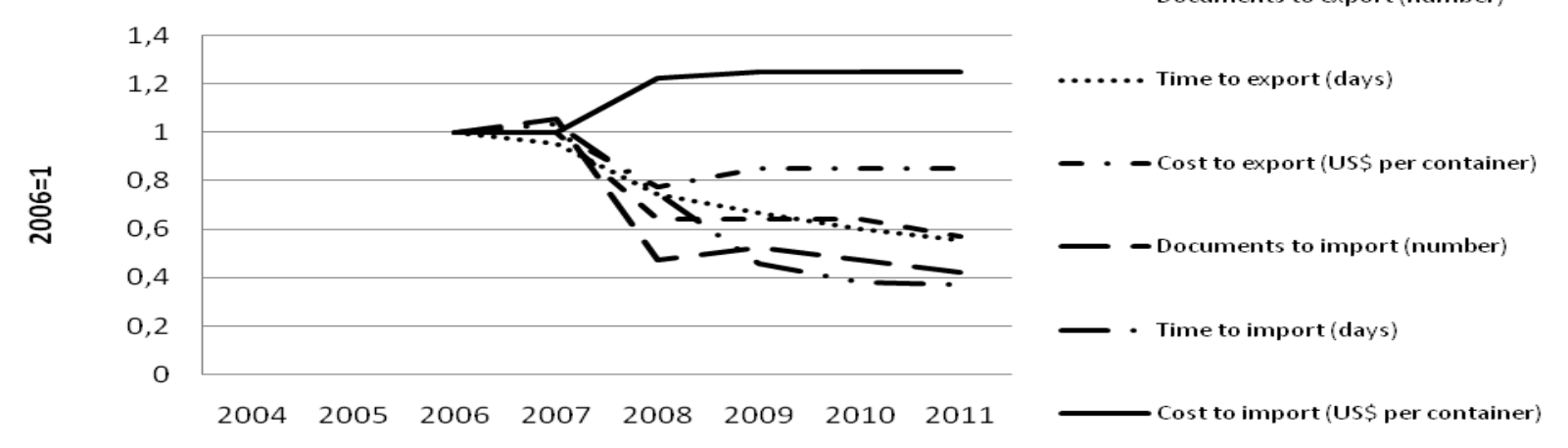

Fig 9: Rwanda: enforcing contracts

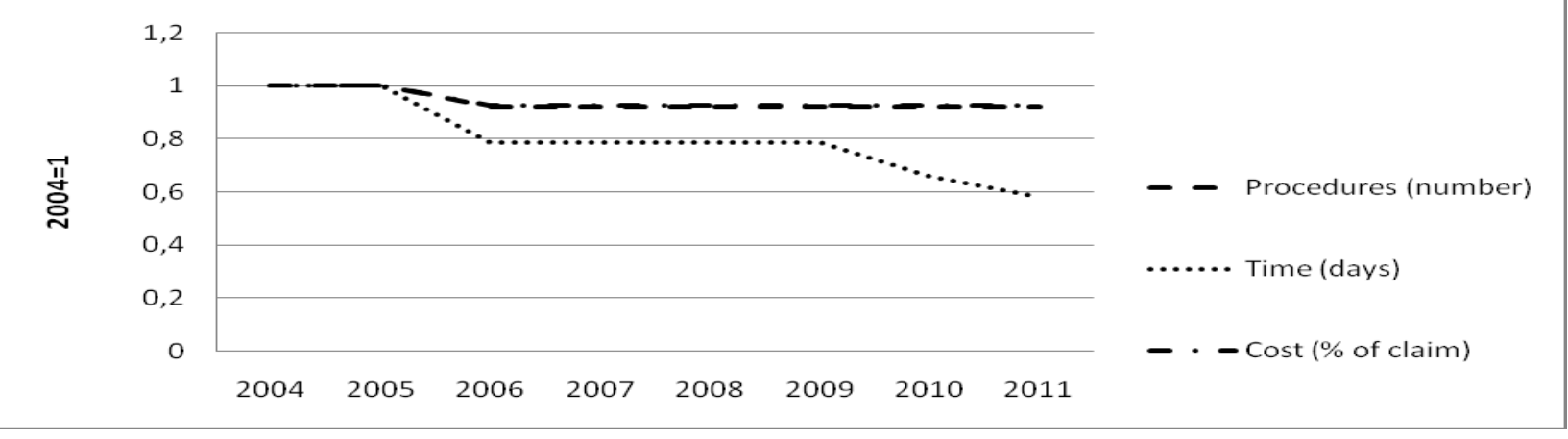

Tables $4 \mathrm{a}$ and $4 \mathrm{~b}$ list the areas of economic reform between 2008 and 2010, based on the Doing Business annual reports 2009 - 2011, and on reports of the Ministry of Trade and Industry, for comparison. According to DB reports, the largest number of reforms (7) occurred in the year 2008/2009, most of the reform activities over the period (3) focused on the financial sector, and here on the credit availability to firms. This table differs considerably from official information provided by the Ministry of Trade and Industry, Government of Rwanda (see Table 7 and Annex 2). There, for 2008/2009 six areas of reform including seven measures are listed, and for 2009/2010 seven areas of reform including 14 measures are listed. The differences in the number of affected areas may be explained by different definitions of dates when regulations become effective. Still, the fact that DB includes government officials among its informers should warrant a single timeline of reforms.

As a supporting illustration only, Table 5 may be used. It shows Rwanda's international rankings with respect to the nine DB indicator sets. However, due to the relative nature of rankings, they do not necessarily show factual improvements. Still, as a worsened regulatory environment has seldom been identified in the DB annual reports, a general and global trend towards improvement may be assumed. In this case. positive changes in rankings point to improvements in the business environment that exceed those of other countries in the same quantile. For Rwanda, positive changes in rankings clearly 
outnumbered negative ones by 6 to 3 and 6 to 2 in the DB reports of 2010 and 2011 , covering the years 2008/09 and 2009/10. In the years before, the positive and negative changes were more or less balanced. This may be taken as am indication of stronger reform activity in the later years.

The various comparisons of data published by the Rwandan government and by DB point to a correct description of both timing and sectoral distribution of business environment reforms by DB.

Table 4a: Reforms in Rwanda 2008-2010 according to DB annual reports

\begin{tabular}{|c|c|c|c|c|c|c|c|c|c|c|}
\hline $\begin{array}{l}\text { Years } \\
\text { covered }\end{array}$ & 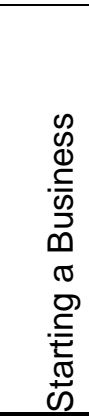 & 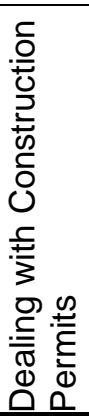 & 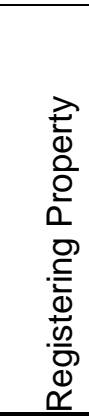 & 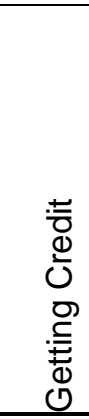 & 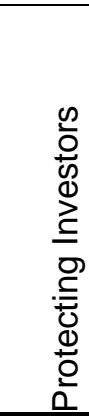 & 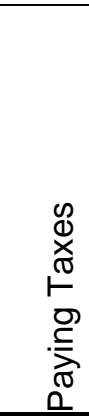 & 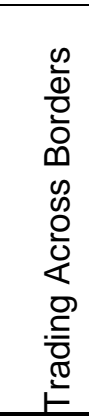 & 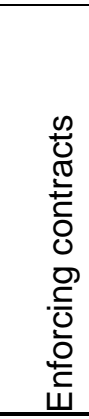 & 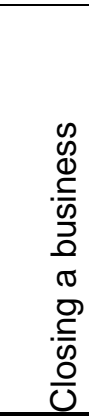 & 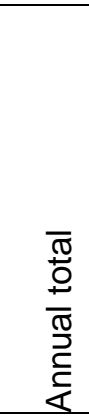 \\
\hline $2007 / 2008$ & & $x$ & & $x$ & & & $x$ & $x$ & & 4 \\
\hline $2008 / 2009$ & $x$ & & $x$ & $x$ & $x$ & $x$ & & $x$ & $X$ & 7 \\
\hline $2009 / 2010$ & & $x$ & & $x$ & & & $x$ & & & 3 \\
\hline $\begin{array}{l}\text { Sector } \\
\text { total }\end{array}$ & 1 & 2 & 1 & 3 & 1 & 1 & 2 & 2 & 1 & 14 \\
\hline
\end{tabular}

Source: based on annual DB reports

Table 4b: Reforms in Rwanda 2008-2010 according to

Government reports

\begin{tabular}{|c|c|c|c|c|c|c|c|c|c|c|}
\hline $\begin{array}{l}\text { Years } \\
\text { covered }\end{array}$ & 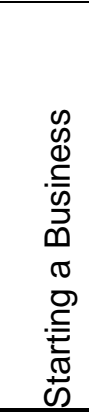 & 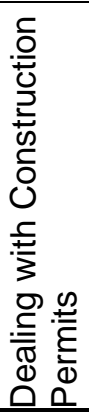 & 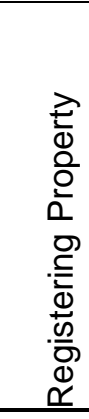 & 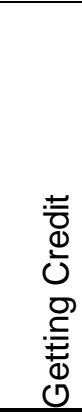 & 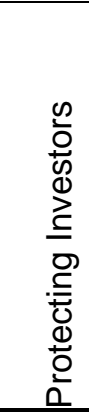 & 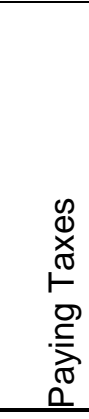 & 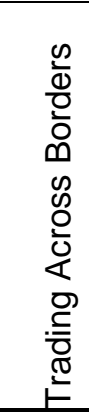 & 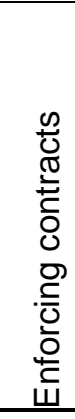 & $\begin{array}{l}0 \\
0 \\
0 \\
\cdot \frac{5}{D} \\
0 \\
0 \\
\sigma \\
0 \\
\frac{D}{0} \\
\frac{0}{0}\end{array}$ & $\begin{array}{l}\bar{\sigma} \\
\frac{\pi}{0} \\
\frac{1}{\pi} \\
\frac{\pi}{2} \\
\frac{c}{\alpha}\end{array}$ \\
\hline \multicolumn{11}{|l|}{$2007 / 2008$} \\
\hline $2008 / 2009$ & 2 & 1 & 1 & 1 & 1 & 1 & & & & 7 \\
\hline $2009 / 2010$ & 1 & 2 & 3 & 1 & & 3 & 4 & & 1 & 14 \\
\hline $\begin{array}{l}\text { Sector } \\
\text { total }\end{array}$ & 3 & 3 & 4 & 2 & 1 & 4 & 4 & 0 & 1 & 21 \\
\hline
\end{tabular}

Source: based on Table 7 


\subsection{Assessment of the regulatory environment in Rwanda in 2008 by DB}

In this section a qualitative assessment of the Rwandan business environment as measured by the DB indicator is attempted. In a later section this will then be compared with the assessment by SBP.

DB does not directly provide information on strengths and weaknesses of a country's regulatory environment. This can only be concluded from a country's relative position in the international ranking. However, an international ranking does not necessarily reflect the valuation of the regulatory environment from a domestic business' perspective; rather, these rankings are indicative of an outsider's perception of Rwanda. This view is taken seriously by the Rwandan government as it cites the international rankings of Rwanda in frequently in its documents (Ministry of Trade and Industry, 2009,24; Ministry of Trade and Industry, 2010,20). Table 5 shows the rankings for Rwanda as published in the respective annual reports. They can be considered to reflect the international perception of the strengths and weaknesses of Rwanda's regulatory environment.

For both DB 2007 and DB 2008 regulation of the financial sector (both investor protection and credit markets) and of foreign trade appear to be relatively unfavorable. Table 4a showed that these areas were attracting above average reform activities during the years 2008 and 2009. On the other hand, enforcing contracts and starting a business were also reformed in two years, despite the fact that rankings in these areas were relatively benign from the beginning. Therefore, it cannot be concluded from the data that the government targeted reforms to those areas that were attracting negative international attention, neither does it prove that these badly ranked areas were in fact areas of major concern to the government, or businesses in Rwanda ${ }^{22}$. However, the government's accelerated reform activities coincided with a drop in the total ranking in DB 2007 from 139 to 158. In other words, the DB data do not provide a conclusive indication of relative strengths or weaknesses of individual regulatory areas in Rwanda as perceived by the local businesses.

\footnotetext{
${ }^{22}$ Still, the government points out: "The reforms were led by the Investment Climate Department in MINICOM and the Doing Business Unit at RDB, co-ordinated by the national Doing Business Taskforce. This team has ensured the carrying through of a number of reforms that have led to the indicator improvements in the Doing Business Report." (Ministry of Trade and Industry, 2009,24)
} 
Table 5: Rwanda's rank with regard to DB indicator sets

\begin{tabular}{|c|c|c|c|c|c|c|c|c|c|c|}
\hline & & $\begin{array}{l}\text { Starting a } \\
\text { Business }\end{array}$ & \begin{tabular}{|c|} 
Dealing with \\
Construction \\
Permits
\end{tabular} & $\begin{array}{c}\text { Registering } \\
\text { Property }\end{array}$ & $\begin{array}{l}\text { Getting } \\
\text { Credit }\end{array}$ & $\begin{array}{l}\text { Protecting } \\
\text { Investors }\end{array}$ & Paying Taxes & $\begin{array}{l}\text { Trading } \\
\text { Across } \\
\text { Borders }\end{array}$ & $\begin{array}{l}\text { Enforcing } \\
\text { Contracts }\end{array}$ & $\begin{array}{l}\text { Closing a } \\
\text { Business }\end{array}$ \\
\hline Year & $\begin{array}{c}\text { Ease of Doing } \\
\text { Business } \\
\text { Rank }\end{array}$ & Rank & Rank & Rank & Rank & Rank & Rank & Rank & Rank & Rank \\
\hline DB2004 & $\ldots$ & .. & $\ldots$ & $\ldots$ & $\ldots$ & $\ldots$ & $\ldots$ & $\ldots$ & .. & $\ldots$ \\
\hline DB2005 & $\ldots$ & ... & $\ldots$ & $\ldots$ & $\ldots$ & $\ldots$ & $\ldots$ & $\ldots$ & .. & $\ldots$ \\
\hline DB2006 & 139. & $\ldots$ & $\ldots$ & $\ldots$ & $\ldots$ & $\ldots$ & $\ldots$ & $\ldots$ &.. &.. \\
\hline \begin{tabular}{|l|} 
DB2007 \\
\end{tabular} & 158 & 58 & 133 & 134 & 159 & 162 & 83 & 175 & 69 & 151 \\
\hline DB2008 & 150 & 63 & 124 & 137 & 158 & 165 & 50 & 166 & 44 & 178 \\
\hline DB2009 & 139 & 60 & 90 & 60 & 145 & 170 & 56 & 168 & 48 & 181 \\
\hline DB2010 & 67 & 11 & 89 & 38 & 61 & 27 & 60 & 170 & 40 & 183 \\
\hline DB2011 & 58 & 9 & 82 & 41 & 32 & 28 & 43 & 159 & 39 & 183 \\
\hline
\end{tabular}

\subsection{Assessment of the regulatory environment in Rwanda in 2008 by RTR}

In this section, the qualitative assessment as measured by the RTR will be described. The results of this assessments can be considered to build the demand side for reforms. This demand will then be compared with the reforms actually undertaken, thus allowing an evaluation of the adequacy of business environment reforms in Rwanda.

The evaluation of the Rwandan business environment by RTR was done in 2008. The survey included 403 companies, of which two thirds are large and medium firms (the firms surveyed constitute $10 \%$ of all large and medium firms in Rwanda.). Of the firms surveyed, 236 were based in the capital, Kigali, the remainder being based in equal shares in the Western, Northern, Southern and Eastern provinces. All sectors of the economy were covered.

Table 6 illustrates the results of the SBP analysis. It lists barriers to business growth in order of importance $e^{23}$ as stated by the respondents. These barriers are then structured in such a way that they can be assigned to the regulatory categories applied by DB.

Apart from the most pressing concern about "lack of demand" 24 , the most important regulatory barrier (here listed as No 1) concerns obtaining financial funds, which can be related to two DB indicator areas (access to credit, investor protection). The third most important barrier concerns taxation, both the level of taxes and the effort of complying with tax laws. The barriers mentioned less

\footnotetext{
${ }^{23}$ It should be noted that the listed barriers are the result of answers to open questions. For detailed results, see (SBP, 2008, 21).

${ }^{24}$ The most important barrier was considered to be lack of demand which is interpreted by the SBP authors as an indication of marketing weaknesses of many firms; it therefore is not a regulatory issue and the analysis does not apply.
} 
frequently are either not of a regulatory nature ("high costs") or are too general ("regulation") or were mentioned by only a small number of respondents. Regulation, according to RTR, is an issue for at least $25 \%$ of respondents.

Taxation, labor regulation and skills emerged as the most important item when respondents were asked to name regulatory issues, constraints on employment, interaction with the government, and "time consuming and troublesome" regulations in more detail (SBP,2008,pp42). In the latter category, business registration and closure were mentioned.

For Rwanda, the order of importance to businesses of these areas proves to be valid across business sectors, firm size and geographical area. Not surprisingly, two of the areas of concern (taxation, Import/Export regimes) were mentioned as priority areas for regulatory reform ${ }^{25}$.

Table 7 disaggregates the concerns of businesses. They are listed from a more general (level 1) to a very specific level (3). These specific concerns are then compared with reform activities of the Rwandan government since 2008. Thus, they can be interpreted as demand for and supply of reforms in Rwanda.

Summarizing demand for and supply of reforms as defined above, reforms were covering all but one indicator set of the DB database. With respect to the 20 more specific concerns of businesses as described by the RTR report, 7 were covered by reforms, and 13 areas were not covered. Did the reforms address the needs of RTR respondents, i.e. of Rwandan businesses? They did with respect to availability of capital, they were partly consistent with RTR revealed need in registration/closure of businesses, and were more or less beside the point (reforming where RTR did not detect demand) in three areas. This points to a bias of reform design towards the DB indicators.

\footnotetext{
${ }^{25}$ It would be interesting to see whether this order of importance appears in other countries, too. SBP has not published any other comparable studies, though. Alternatively, a cross country analysis of the World Bank's enterprise survey data (which are also perception based) could be attempted.
} 
Table 6: Areas and adequacy of Rwandan regulatory reform

\begin{tabular}{|c|c|c|}
\hline Area of reform & $\begin{array}{l}\text { Demand } \\
\text { mostly } \\
\text { met? }\end{array}$ & Detailed description \\
\hline $\begin{array}{l}\text { 1. Access to } \\
\text { capital }\end{array}$ & Yes & $\begin{array}{l}\text { The most important area of concern, lack of capital, was tackled } \\
\text { by two reforms in } 2008 / 09 \text { and one further reform in the following } \\
\text { year. These reforms provide for regulations that deal with the } \\
\text { most pressing needs of borrowers and lenders, i.e. pledging } \\
\text { mobile collateral and establishment of a credit registry. The latter } \\
\text { is confirmed by data in Figure } 5 \text {. }\end{array}$ \\
\hline 2. Taxation & partly & $\begin{array}{l}\text { The second most important area of concern, taxation, was } \\
\text { covered by one reform in } 2008 / 09 \text { and another three measures in } \\
2009 / 10 \text {. The reforms make the process of declaring tax easier, } \\
\text { but they fail to deal with the issue of communication with RRA, } \\
\text { which can be rooted to lack of skills and inefficient organizational } \\
\text { structures within RRA. Also, the decision on and level of penalties } \\
\text { were not tackled. }\end{array}$ \\
\hline $\begin{array}{l}\text { 3. Registration/ } \\
\text { closure of } \\
\text { business }\end{array}$ & $\begin{array}{l}\text { Supply > } \\
\text { demand }\end{array}$ & $\begin{array}{l}\text { Registration and closure of businesses constitutes another area of } \\
\text { concern. Neither of these areas was specified by respondents; } \\
\text { nonetheless, the first was the subject of reforms: opening a } \\
\text { business has been made more easy through two reforms in each } \\
\text { year, business closure issues were not dealt with. }\end{array}$ \\
\hline 4. Labor & no & $\begin{array}{l}\text { The area of labor regulations was not specified as a high ranking } \\
\text { area of concern by respondents. However, the RTR spelled out } \\
\text { the weaknesses under the heading "regulation" in detail. Still, no } \\
\text { reforms were undertaken in the two years, with the exception of } \\
\text { online income and value added tax payments. The liberalization of } \\
\text { work permits for foreigners preceded that time. }\end{array}$ \\
\hline 5. Trade & Partly & $\begin{array}{l}\text { Weaknesses in the area of foreign trade regulation, presumed to } \\
\text { be included in concerns about regulation in general, was } \\
\text { described in more detail in the RTR, too. Here, of five } \\
\text { weaknesses listed in RTR, two were covered by reforms in the } \\
\text { second year. They mostly dealt with speedier processing of } \\
\text { documents, whereas complaints about ineffective and } \\
\text { insufficiently skilled staff where not covered. }\end{array}$ \\
\hline 6. Other & $\begin{array}{l}\text { Supply > } \\
\text { demand }\end{array}$ & $\begin{array}{l}\text { Areas not mentioned by businesses in the RTR like registration of } \\
\text { property issuing of construction permits where covered by one } \\
\text { reform each in } 2008 / 09 \text { and two reforms each in } 2009 / 10 \text {. } \\
\text { Incidentally, those areas (like opening and closing a business, see } \\
\text { above, feature prominently on the Doing Business list of } \\
\text { indicators. }\end{array}$ \\
\hline
\end{tabular}

The demand/supply approach to reforms may provide a political economy type of explanation. A different tack would be taken if the government is assumed to behave as a benevolent dictator. In this case its goal would be to reduce the cost of regulation ${ }^{26}$.

The RTR offers insights into the cost of regulation to businesses (SBP,2008, ch.7). A hypothesis for how the government prioritizes reforms is to assume that most costly regulations would be tackled either first or most intensively.

${ }^{26}$ Gross cost, as regulation benefits are not addressed 


\section{Figure 10: Regulatory Cost in Rwanda, 2008}

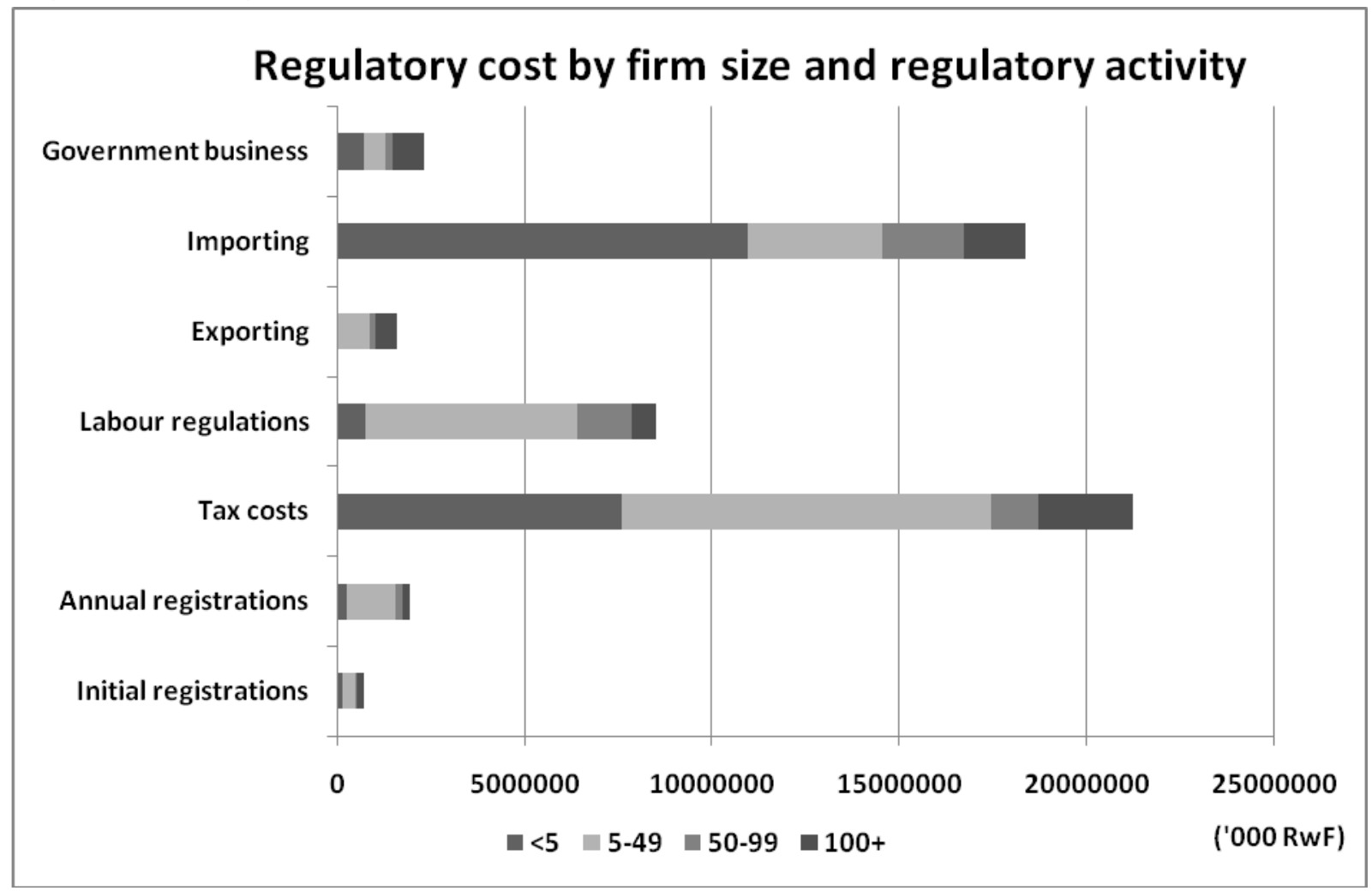

Figure 10 provides an overview of regulatory reform for five firm size groups, measured by the number of employees $(<5,5-49,50-99,100+)^{27}$. Clearly, taxation and inbound trade constitute the activities that suffer from the most expensive regulations. In fact, both areas are covered by the reforms. The government based reform count (see Table $4 \mathrm{~b}$ ) reflects the cost determined priorities more strongly than the reform count by DB. This might be due to both the high political visibility that the RTR's cost calculations activities had. Also the Public Private Dialogue mechanism ${ }^{28}$ underlying the Economic cooperation program of which RTR is a part may have contributed to this effect.

It cannot be excluded that the use of cost estimates has a stronger effect on the government's reform efforts than non-monetized indicators. (i.e. the pure responses to either the fact based or perception based questionnaires). This makes the cost based approach a potentially powerful tool for reform design.

\footnotetext{
${ }^{27}$ The seemingly lower cost for larger firms is due to the small number of large firms; e.g. the sample underlying RTR contained up to 21000 small firms, and up to 112 large firms.

${ }^{28}$ This was confirmed by Emmanuel Hategeka, Permanent Secretary, Ministry of Trade and Industry.
} 
Table 7: Demand for and supply of regulatory reform in Rwanda, 2008-2010

\begin{tabular}{|c|c|c|c|c|c|}
\hline $\begin{array}{l}\text { Level 1: general } \\
\text { business barriers }\end{array}$ & $\begin{array}{l}\% \text { of } \\
\text { res- } \\
\text { pon- } \\
\text { dents }\end{array}$ & $\begin{array}{l}\text { Level 2: } \\
\text { regulation } \\
\text { (DB areas) }\end{array}$ & Level 3: specific regulatory barrier & Reforms 2008/2009 & Reforms 2009/2010 \\
\hline Lack of demand & $>35$ & n.a. & & & \\
\hline \multirow[t]{2}{*}{ Lack of capital } & $>35$ & Getting credit & Difficulty in establishing collateral & Mobile collateral possible & Credit registry \\
\hline & & $\begin{array}{l}\text { Protecting } \\
\text { investors }\end{array}$ & & Bankruptcy law & \\
\hline \multirow[t]{8}{*}{ Tax } & \multirow[t]{7}{*}{$>25$} & \multirow{7}{*}{$\begin{array}{l}\text { Tax } \\
\text { compliance }\end{array}$} & Waiting time at tax offices & & Quarterly payments for SME \\
\hline & & & Travel time to tax office & $\begin{array}{l}\text { Additional bank licensed for tax } \\
\text { payments }\end{array}$ & $\begin{array}{l}\text { Online tax registration; } \\
\text { Decentralized tax services }\end{array}$ \\
\hline & & & $\begin{array}{l}\text { Penalties for late payment, even if } \\
\text { caused by RRA }\end{array}$ & & \\
\hline & & & Multiple points of contact & & \\
\hline & & & Communication from RRA & & \\
\hline & & & Verification process & & $\begin{array}{l}\text { Online tax calculators for PAYE, } \\
\text { VAT }\end{array}$ \\
\hline & & & Audits & & \\
\hline & & Tax level & & & \\
\hline Competition & $>10$ & n.a. & & & \\
\hline \multirow[t]{8}{*}{ Regulations } & \multirow[t]{8}{*}{$>5$} & \multirow[t]{2}{*}{$\begin{array}{l}\text { Business } \\
\text { registration }\end{array}$} & & $\begin{array}{l}\text { Registration streamlined from } \\
14 \text { days to } 24 \mathrm{~h}\end{array}$ & \\
\hline & & & & Registration fee reduced & Online business registration \\
\hline & & $\begin{array}{l}\text { Business } \\
\text { closure }\end{array}$ & & & $\begin{array}{l}\text { Registration fees can be paid at } \\
\text { any Bank of Kigali branch }\end{array}$ \\
\hline & & $\begin{array}{l}\text { Import } \\
\text { regulations }\end{array}$ & See below foreign trade & & \\
\hline & & \multirow[t]{4}{*}{$\begin{array}{l}\text { Employing } \\
\text { workers }\end{array}$} & $\begin{array}{l}\text { Lack of information and/or poor } \\
\text { understanding of labor regulations }\end{array}$ & & \\
\hline & & & Administrative issues, skills of staff & & \\
\hline & & & $\begin{array}{l}\text { Difficulties accessing work permits } \\
\text { for foreign workers }\end{array}$ & & \\
\hline & & & Dismissal of employees, high & & \\
\hline
\end{tabular}




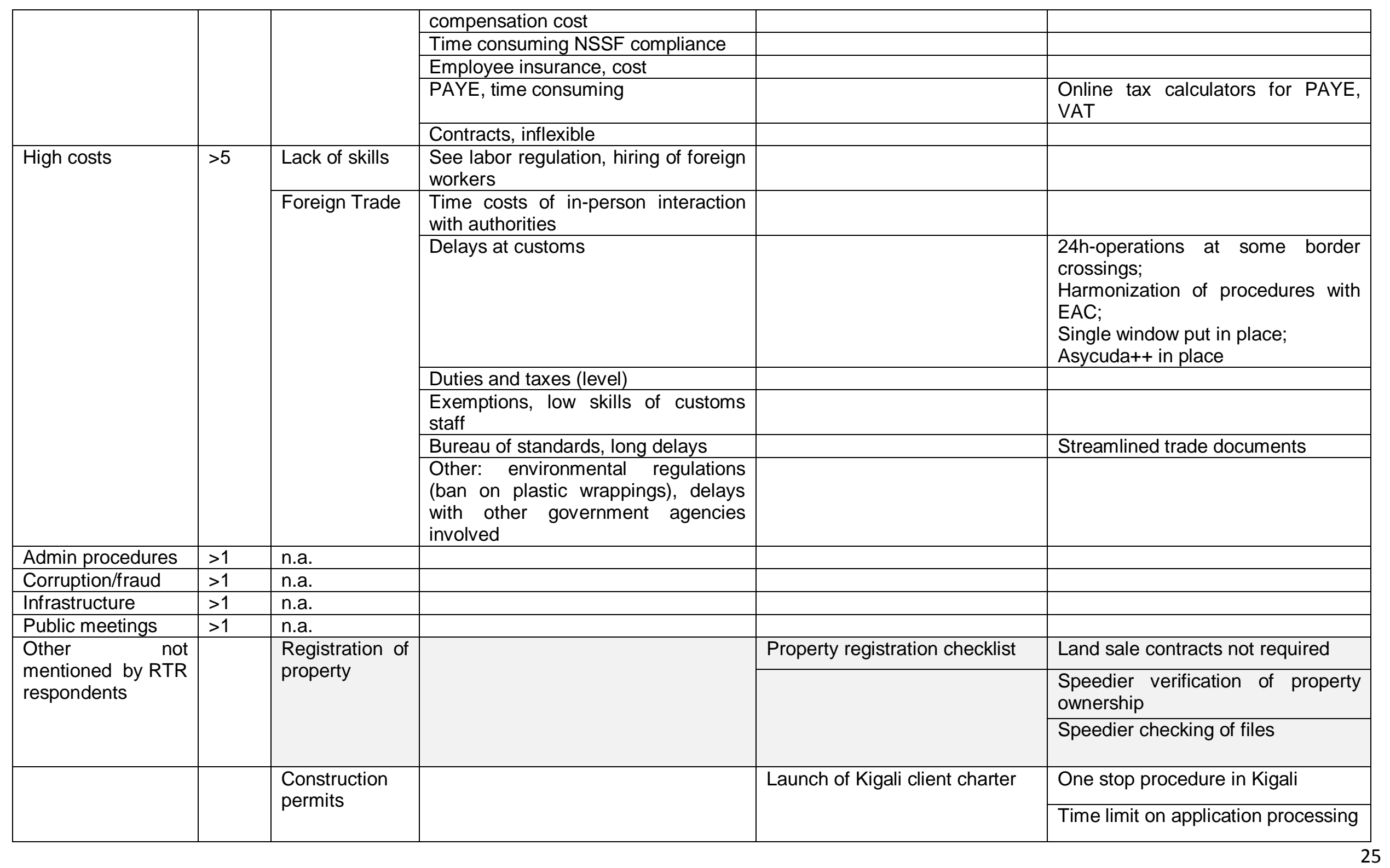


3.5. Results of the sample survey in $2010^{29}$

In this section, the assessment of regulatory reform in Rwanda since 2008 is contrasted with the results obtained during a survey mission in November 2010. Following the method applied in section 3.4, the survey asked respondents about regulatory hurdles in the areas defined by the DB indicators. The goal is to find out whether the reforms decreed by the government and measured by DB were effective "on the ground", i.e. whether businesses actually felt a clear improvement in these areas. Hence, the 2010 survey combined elements of the SBP approach (perception based survey) with elements of DB (pre-defined criteria) and thus allows an evaluation of the DB results.

In November 2010, managers from 12 private sector businesses, two banks, two government agencies, two universities and one business association were interviewed. Of the businesses, five belong to the service sector, one to the agricultural sector, and six to the manufacturing sector. Turnover ranged from FRW 35m to FRW 5500, fixed employment ranged from 15 to 700 persons, and nine firms directly or indirectly ${ }^{30}$ were involved in cross border transactions. Businesses were located in the urban area of the capital, Kigali (9), in the provincial center area of Butare (2), and one in rural areas. All the firms had been subject to the SBP exercise in 2008.

The goal of the interviews was to evaluate the effects of latest regulatory reforms "on the ground", i.e. whether these reforms have effectively solved businesses' problems that were either mentioned by the SBP report ${ }^{31}$ or that showed a belowaverage ranking in the $\mathrm{DB}$ indicators.

The interviews were of a semi-open question type; the managers were asked to describe the situation regarding the nine DB indicator sets, plus the issue of labour legislation ("Employing workers" in earlier DB rankings). The (open) answers were then coded regarding their degree of meeting the goals of the regulatory reform listed by $\mathrm{DB}$, ranging from +1 (100\% effectiveness of reform) to -1 (no effectiveness at all).

In table 8 below, the responses for the results for the indicators are listed in their order of evaluation, with a high positive mean indicating that the regulatory burdens in the concerned DB indicator group were felt on the ground; conversely, a high negative mean would indicate that no relief from regulatory burdens was felt in the indicator group.

\footnotetext{
${ }^{29}$ The field survey was commissioned by GTZ, Rwanda.

${ }^{30}$ Indirectly is defined as using imported materials or products and having to comply with regulations concerning usage of foreign goods or their maintenance.

${ }^{31}$ All firms were involved in the survey underlying the RTR of 2008.
} 
Reforms with regard to indicators starting a business and registering property were perceived as being most successful, whereas getting credit and closing a business were seen as the least successful areas of regulatory reform.

Table 8: Perception of regulatory reforms by business managers

\begin{tabular}{|c|c|c|}
\hline DB Indicator & Mean & Description \\
\hline $\begin{array}{l}\text { Starting } \\
\text { business }\end{array}$ & $+0,8$ & $\begin{array}{l}\text { Most managers evaluated the process of opening a business very } \\
\text { positively. However, two of them also reported that the situation was } \\
\text { as easy before 2008. Most of them reported that apart from the } \\
\text { registration process, other difficulties which were not tackled by } \\
\text { reforms remain }\end{array}$ \\
\hline $\begin{array}{l}\text { Registering } \\
\text { Property }\end{array}$ & +0.3 & $\begin{array}{l}\text { Experiences of managers diverged strongly. In some cases, recent } \\
\text { registration took } 21 \text { months, in other cases it was considered to be } \\
\text { very easy. One stop agencies were established at locations outside } \\
\text { Kigali, too, but still the required documents to get a title have to be } \\
\text { obtained from lower level agencies which have not been reformed } \\
\text { and which contribute to the cumbersome nature of procedures. }\end{array}$ \\
\hline $\begin{array}{l}\text { Employing } \\
\text { Workers }\end{array}$ & 0 & $\begin{array}{l}\text { The existing laws were seen as less problematic than the lack of } \\
\text { skills. In this respect, the laws governing employment of foreigners } \\
\text { were seen as restrictive; this pertains to related areas, like payments } \\
\text { to NSSF for expats, too. Another complaint referred to high and } \\
\text { unpredictable compensation payments once employees have to be } \\
\text { laid off. Generally, the hiring of workers was not seen as a problem if } \\
\text { lawyers are setting up the contracts. }\end{array}$ \\
\hline $\begin{array}{l}\text { Enforcing } \\
\text { contracts }\end{array}$ & -0.2 & $\begin{array}{l}\text { Managers know about the reforms (establishment of business case } \\
\text { courts), but still do not see the legal system as a viable option to } \\
\text { enforce contracts. The reasons given are long time for decisions, } \\
\text { dependent courts and corruption, as well as a large share of cash } \\
\text { based transactions that are not reported to the authorities, and hence } \\
\text { not enforceable. }\end{array}$ \\
\hline $\begin{array}{l}\text { Construction } \\
\text { permits }\end{array}$ & -0.3 & $\begin{array}{l}\text { MeanRespondents stressed that severe regulatory hurdles exist at } \\
\text { lower levels of decision-making. Fast track construction permissions } \\
\text { require the submission of documents that have to be issued at } \\
\text { district or local levels, where long delays still are common. Also, } \\
\text { complaints about unskilled officials and the necessity to obtain } \\
\text { permissions for minor changes of existing buildings were mentioned. } \\
\text { Furthermore, heavy handed regulation in other related areas (e.g. } \\
\text { the Kigali masterplan for inner city development requires owners of } \\
\text { property to increase covered area by } 400 \% \text { ) make construction per } \\
\text { se more difficult. }\end{array}$ \\
\hline Paying taxes & -0.3 & $\begin{array}{l}\text { Most managers complained that online payments were not possible; } \\
\text { online registration was appreciated, though. A major problem } \\
\text { appears to be tax audits, due to unskilled staff and harsh payment } \\
\text { conditions. Also, the skills of tax officials regarding tax assessment } \\
\text { were often questioned. VAT payments were seen as a strain on cash } \\
\text { flow, as payments have to be made when the bill is issued, not when } \\
\text { payment is received. This pushes many firms into cash payments, } \\
\text { which in turn reduces efficiency of the financial system as a whole }\end{array}$ \\
\hline
\end{tabular}




\begin{tabular}{|l|l|l|}
\hline & & $\begin{array}{l}\text { and reduces the transparency for the tax authorities. In fact, } \\
\text { respondents, when asked about the opportunities to enforce } \\
\text { contracts (see below), mentioned that courts are not a viable option } \\
\text { because many transactions were cash based and not reported to the } \\
\text { tax authorities. }\end{array}$ \\
\hline $\begin{array}{l}\text { Trading across } \\
\text { borders }\end{array}$ & -0.4 & $\begin{array}{l}\text { Generally, processes were sped up, but lacking skills of customs } \\
\text { officials lead to disputes over customs valuation in many cases. } \\
\text { These problems lead to a delay outside the activities covered by the } \\
\text { reforms. }\end{array}$ \\
\hline $\begin{array}{l}\text { Closing } \\
\text { business }\end{array}$ & -0.5 & $\begin{array}{l}\text { Generally the law is seen as good, but ineffective because } \\
\text { bankruptcy is not an option for other reasons: most managers } \\
\text { responded that a defaulter would be denied access to credit in the } \\
\text { future, and that claims could not be effectively recovered through the } \\
\text { courts. Therefore, the reform seems not have been effective yet }\end{array}$ \\
\hline Getting credit & -0.5 & $\begin{array}{l}\text { Most managers complained about the inability to secure loans with } \\
\text { mobile (working) capital. One respondent mentioned a credit window } \\
\text { against mobile collateral at a Kenyan bank. Here clearly the reforms } \\
\text { have not been effective on the ground; based on interviews with } \\
\text { bank managers, this seems to be due to the banks which are } \\
\text { particularly risk averse at the time of the financial crisis and therefore } \\
\text { do not adopt the latest changes in regulation }\end{array}$ \\
\hline $\begin{array}{l}\text { Protecting } \\
\text { investors }\end{array}$ & n.a. & \begin{tabular}{l} 
no statements were made regarding this indicator \\
\hline
\end{tabular} \\
\hline
\end{tabular}

Summing up, very diverse responses of managers do not convey a clear picture of the regulatory situation at the end of 2010 . The average of all responses was slightly negative (-0.03), i.e. respondents in November 2010 did not perceive the reforms undertaken since 2008 to clearly have improved the business environment as measured and defined by the DB indicator sets. The small sample size does not provide statistically significant results of the interviews. However, the responses of the generally well informed business managers are indicative of the (post-2008-) reform regulatory situation in Rwanda.

The below graph illustrates the perception of reforms by the business managers interviewed in November 2010. In two areas (starting a business, registering property) respondents on average saw improvements of the regulatory environment, although in no area was there unanimous agreement on the improvements. In the six ${ }^{32}$ remaining areas respondents perceived the situation as not reflecting reform efforts; the least progress was made with respect to capital availability, trade and closing a business.

\section{Figure 11: Summary perceptions of reform effects}

${ }^{32}$ Investor protection was not commented by respondents 


\section{Perception of reforms on the ground}

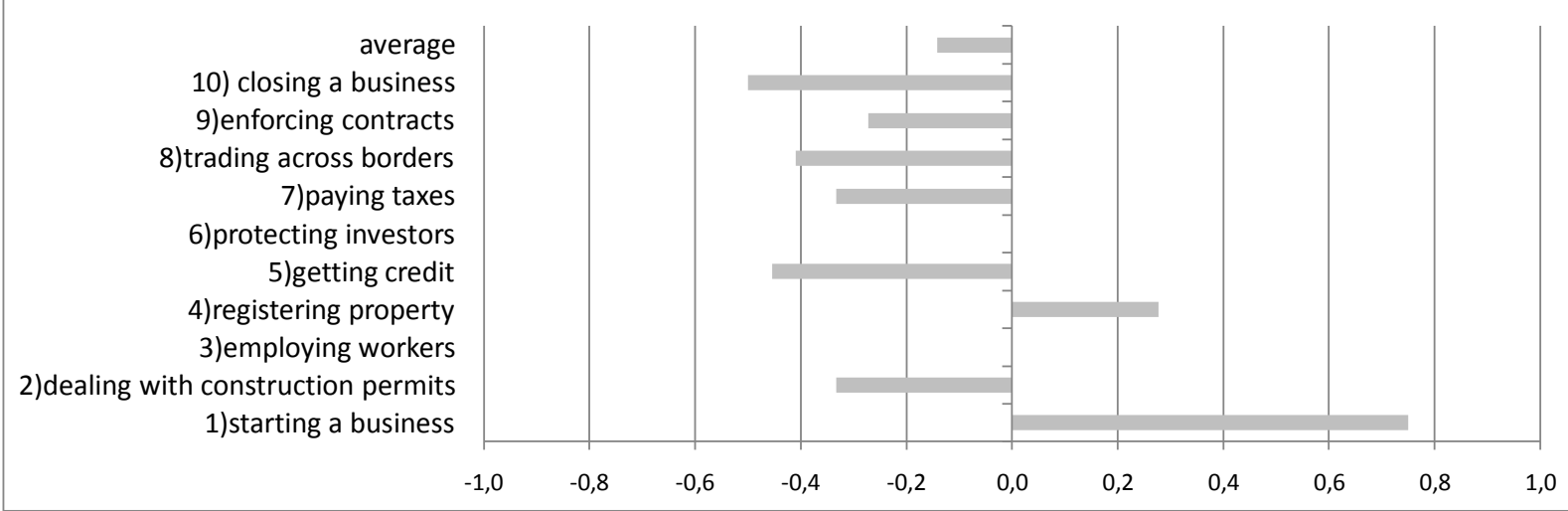

These results compare with the reform measures listed in table 7 (level1). There, cumbersome trade regulation was mentioned as a severe problem, a view confirmed by the interviews of 2010. However, reforms addressed only a few of the specific regulatory problems (processing time), but did not tackle the issue of skills in the RRA. Regulation of credit markets did not address the problems sufficiently either, as the reforms were not taking into consideration the reluctance of banks to make use of the new regulation. Perception of the tax regime has only partly been perceived as improved, because valuation issues (in tax assessment and in audits) and cash flow issues were not addressed by the reforms. However, the time savings allowed by the new regulations was appreciated by most businesses $^{33}$. Finally, respondents on average were neutral towards labor regulations, although these were listed specifically in the SBP report.

The general conclusion that reforms did not target the most pressing needs of businesses is supported when the results of the 2010 survey are compared with the timeline and strength of reforms as measured by DB and illustrated in graphs 2 to 9 . Only in the indicator groups "starting a business" and "registering property" did respondents in 2010 confirm that the strong reforms suggested by DB actually had had an effect "on the ground", i.e. were felt by business managers. For four indicator groups that showed strong improvement in DB (enforcing contracts, trade, paying taxes, getting credit) business managers did on average not report an improvement of their situation. This, too, points to a low reliability of DB indicators to describe the actual regulatory situation of local businesses in Rwanda.

\subsection{Conclusion}

The reforms undertaken by the Rwandan government addressed areas of concern of Rwandan businesses. However, they did not fully reflect the priorities

33 Interestingly, construction permits, enforcement of contracts and procedures for closing a business, areas not highlighted in 2008 , were now identified as areas of concern 
set by respondents of the RTR and they did not always prove to be effective on the ground even in areas that were of major concern to local businesses.

Generally, the reforms seem to be geared toward covering areas that are listed in the DB indicator sets. Other criteria for an effective and efficient regulatory environment, like those mentioned by respondents of the RTR in 2008, seem to have been of lower priority to the government.

In can therefore be concluded, that the (perception based) method underlying the RTR more clearly spells out the problems businesses have with existing regulation than the (fact based) method of DB does. This is particularly true when a cost based assessment of the regulator environment is considered. Whether and how a regulatory analysis that spells out the cost of mis-regulation affects government decision making is not subject of this analysis. Therefore a generalization of this result should not be made.

DB seems to overstate the actual improvement in the regulation of local businesses. This result is confined to the situation in Rwanda. Therefore, a cross country analysis of DB results may produce a braoder based conclusion regarding the suitability of DB for measuring a country's business environment.

\section{Summary Conclusion}

1. Existing research shows that the link between business environment and economic growth is not yet fully clear.

2. The methods of business environment assessment differ. The most prominent method is fact based and applied by the World Bank's Doing business project. An alternative is the evidence/perception based approach used in Rwanda in the broader context of a development cooperation project.

3. For Rwanda, perception based (SBP) and fact based (DB) approaches do not yield the same results regarding the demand for regulatory reform.

4. The supply of reforms appears to be geared to the reform deficiencies as defined by DB. However, when regulatory cost is considered, the perception based approach also seems to be in line with the reform activities of the Rwandan government.

5. The effectiveness of reforms undertaken in Rwanda varies. Based on interviews in late 2010, of the eight areas defined by the DB indicators, reforms on average were rather not effective in five areas, rather effective in two areas, and neutral in one. This rather neutral perception of the Rwandan business environment quality after two years of intensive reforms contrasts with the strong improvement of Rwanda in the DB international country rankings (from rank 150 in the DB 2008 report to rank 58 in the DB 
2011 report). Due to the small sample size of the 2010 survey, the results of this survey have to be interpreted with great care, though.

There is need for further research on the subject of assessment and effectiveness of regulatory reform. Problems arising from rankings (the density per quantile determines changes in rankings), effects of perception based vis-à-vis fact based assessment methods on a broader base, and the political economy framework of a country as determinant of reform orientation deserve more empirical research. Last not least, the effect of business environment on growth is not yet established and requires further attention. This issue, when discussed together with political economy criteria, may yield interesting results regarding what "good governance" constitutes in general and the mechanics of regulatory reform in particular. 


\section{Annex 1: DB indicator sets}

\begin{tabular}{|c|c|}
\hline Indicator & Subindicator \\
\hline \multirow{4}{*}{$\begin{array}{l}\text { Starting a } \\
\text { Business }\end{array}$} & Procedures (number) \\
\hline & Time (days) \\
\hline & Cost (\% of income per capita) \\
\hline & Min. capital (\% of income per capita) \\
\hline \multirow{3}{*}{$\begin{array}{l}\text { Dealing with } \\
\text { Construction } \\
\text { Permits }\end{array}$} & Procedures (number) \\
\hline & Time (days) \\
\hline & Cost (\% of income per capita) \\
\hline \multirow{3}{*}{$\begin{array}{l}\text { Registering } \\
\text { Property }\end{array}$} & Procedures (number) \\
\hline & Time (days) \\
\hline & Cost (\% of property value) \\
\hline \multirow{4}{*}{ Getting Credit } & Strength of legal rights index $(0-10)$ \\
\hline & Depth of credit information index (0-6) \\
\hline & Public registry coverage (\% of adults) \\
\hline & Private bureau coverage ( $\%$ of adults) \\
\hline \multirow{4}{*}{$\begin{array}{l}\text { Protecting } \\
\text { Investors }\end{array}$} & Extent of disclosure index $(0-10)$ \\
\hline & Extent of director liability index $(0-10)$ \\
\hline & Ease of shareholder suits index $(0-10)$ \\
\hline & Strength of investor protection index $(0-10)$ \\
\hline \multirow{6}{*}{ Paying Taxes } & Payments (number per year) \\
\hline & Time (hours per year) \\
\hline & Profit tax (\%) \\
\hline & Labor tax and contributions (\%) \\
\hline & Other taxes (\%) \\
\hline & Total tax rate (\% profit) \\
\hline \multirow{6}{*}{$\begin{array}{l}\text { Trading Across } \\
\text { Borders }\end{array}$} & Documents to export (number) \\
\hline & Time to export (days) \\
\hline & Cost to export (US\$ per container) \\
\hline & Documents to import (number) \\
\hline & Time to import (days) \\
\hline & Cost to import (US\$ per container) \\
\hline \multirow{3}{*}{$\begin{array}{l}\text { Enforcing } \\
\text { Contracts }\end{array}$} & Procedures (number) \\
\hline & Time (days) \\
\hline & Cost (\% of claim) \\
\hline \multirow{3}{*}{$\begin{array}{l}\text { Closing a } \\
\text { Business }\end{array}$} & Recovery rate (cents on the dollar) \\
\hline & Time (years) \\
\hline & Cost (\% of estate) \\
\hline
\end{tabular}


Annex 2: Reforms undertaken 2008 - 2010

\begin{tabular}{|c|c|c|}
\hline Indicator & $2008 / 2009$ & $2009 / 2010$ \\
\hline \multirow{2}{*}{$\begin{array}{l}\text { Starting a } \\
\text { Business }\end{array}$} & $\begin{array}{l}\text { Company registration streamlined } \\
\text { from } 9 \text { procedures in } 14 \text { days } \\
\text { (World Bank standardestimate) to } \\
2 \text { procedures in } 24 \text { hours, all to be } \\
\text { done at the One Stop Centre. }\end{array}$ & $\begin{array}{l}\text { Online business registration is now } \\
\text { operational. This means that a } \\
\text { company may be incorporated remotely } \\
\text { or abroad without necessarily coming to } \\
\text { RDB. For details, visit www.rdb.rw }\end{array}$ \\
\hline & $\begin{array}{l}\text { Company registration costs } \\
\text { reduced from the Rwf } 12,000- \\
\text { Frw } 100,000 \text { ranges to flat fee of } \\
\text { Rwf } 25,000 \text { irrespective of type } \\
\text { and number of activities. }\end{array}$ & $\begin{array}{l}\text { Payment of registration fees may be } \\
\text { done in cash or with a Bank of Kigali } \\
\text { point of sale (POS) that accepts } \\
\text { international cards. }\end{array}$ \\
\hline \multirow{3}{*}{$\begin{array}{l}\text { Dealing with } \\
\text { Construction } \\
\text { Permits }\end{array}$} & $\begin{array}{l}\text { The launch of Kigali MVK client } \\
\text { charter outlining the procedures of } \\
\text { acquiring construction permits: the } \\
\text { issuing agencies and the time } \\
\text { limits within which a } \\
\text { business/individual should have } \\
\text { all the construction paper work } \\
\text { done. In addition an Electrogaz } \\
\text { delegate was placed at the one } \\
\text { stop centre to facilitate } \\
\text { connections to utilities for } \\
\text { investors }\end{array}$ & $\begin{array}{l}\text { A Prime Ministerial order } \\
\text { legalizing/enforcing time limits for the } \\
\text { delivery of construction permits } \\
\text { according to the client charter and } \\
\text { instituting sanctions for failure to deliver } \\
\text { has been gazette and is being } \\
\text { enforced. An appeal mechanism for } \\
\text { applicants has also been established. } \\
\text { Average time has reduced from } 210 \\
\text { days to less than } 30 \text { days to obtain a } \\
\text { construction permit. }\end{array}$ \\
\hline & & $\begin{array}{l}\text { A one stop construction permit centre } \\
\text { has been established and housed in the } \\
\text { Nyarugenge district offices to ease } \\
\text { construction and ensure the time } \\
\text { prescribed by the client charter is } \\
\text { respected. The results already speak } \\
\text { for themselves. For details please visit: } \\
\text { www.kigalicityconstructionosc.gov.rw }\end{array}$ \\
\hline & & $\begin{array}{l}\text { Procedures have been reduced with a } \\
\text { merger of all inspections done into one } \\
\text { procedure (inspections of land, } \\
\text { electricity and water). A public notice } \\
\text { has been issued by the Mayor of Kigali } \\
\text { city and published in the official gazette. }\end{array}$ \\
\hline \multirow[t]{3}{*}{$\begin{array}{l}\text { Registering } \\
\text { Property }\end{array}$} & $\begin{array}{l}\text { Improvements in the process of } \\
\text { property registration with the } \\
\text { introduction of a checklist list of all } \\
\text { documentary requirements by } \\
\text { RRA together with land registry } \\
\text { when carrying out property } \\
\text { transfers. }\end{array}$ & $\begin{array}{l}\text { The National Land Centre has } \\
\text { abolished the requirement to formulate } \\
\text { a sale contract cutting back on time to } \\
\text { formalize title deeds. }\end{array}$ \\
\hline & & $\begin{array}{l}\text { Reduction in time to verify property } \\
\text { ownership to less than } 10 \text { days instead } \\
\text { of } 60\end{array}$ \\
\hline & & $\begin{array}{l}\text { Streamlining of file checking with } \\
\text { introduction of checklists }\end{array}$ \\
\hline \multirow[t]{2}{*}{$\begin{array}{l}\text { Getting } \\
\text { Credit }\end{array}$} & $\begin{array}{l}\text { The Secured Transaction law will } \\
\text { make it easier for businesses to } \\
\text { obtain credit by allowing them to } \\
\text { use almost any type of movable } \\
\text { asset as collateral in loan } \\
\text { transactions }\end{array}$ & $\begin{array}{l}\text { Improvements to the public credit } \\
\text { registry have been implemented } \\
\text { widening the data to cover } 2 \text { years of } \\
\text { credit information and incorporate } \\
\text { information on utilities. }\end{array}$ \\
\hline & & $\begin{array}{l}\text { A private bureau has gone online by } \\
\text { CRB Africa widening its scope to cover } \\
\text { banking, insurance, and utilities' } \\
\text { (electricity, } \quad \text { water }\end{array}$ \\
\hline
\end{tabular}




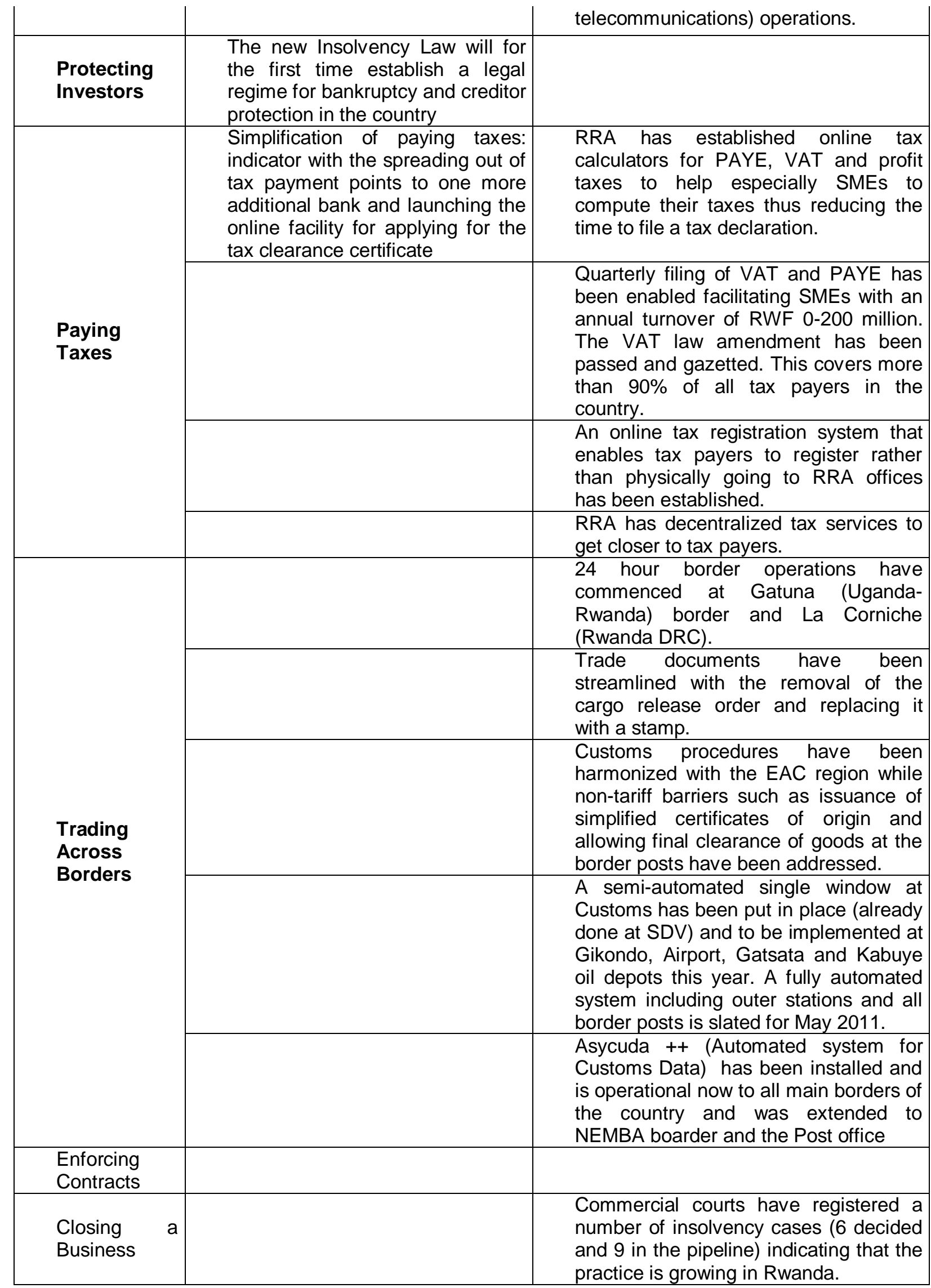

Source: (Ministry of Trade and Industry, 2009,25); (Ministry of Trade and Industry, 2010, 20) 


\section{Annex 3: DB assumptions for the standardized business case}

The business...

- Is a limited liability company. If there is more than one type of limited liability company in the economy, the limited liability form most popular among domestic firms is chosen. Information on the most popular form is obtained from incorporation lawyers or the statistical office.

- Operates in the economy's largest business city. It is $100 \%$ domestically owned and has 5 owners, none of whom is a legal entity.

- Has start-up capital of 10 times income per capita at the end of 2009, paid in cash.

- Performs general industrial or commercial activities, such as the production or sale to the public of products or services. The business does not perform foreign trade activities and does not handle products subject to a special tax regime, for example, liquor or tobacco. It is not using heavily polluting production processes.

- Leases the commercial plant and offices and is not a proprietor of real estate.

- Does not qualify for investment incentives or any special benefits.

- Has at least 10 and up to 50 employees 1 month after the commencement of operations, all of them nationals.

- Has a turnover of at least 100 times income per capita.

- Has a company deed 10 pages long.

Source: (World Bank,2010,113-114) 


\section{Bibliography}

Alesina, Alberto, Silvia Ardagna, Giuseppe Nicoletti, and Fabio Schiantarelli (2005): Regulation and Investment Journal of the European Economic Association June 2005 3(4):791-825

Bougignon, F. and P. Blescovic (2006): Growth and Integration. Annual World Bank Conference on Development Economics, 2006

CFIB (2010): Prosperity Restricted by Red Tape. Canadian Federation of Independent Businesses, $2^{\text {nd }}$ edition, Toronto

Ciccone, Antonio and Elias Papaioannou (2007): Red Tape and Delayed Entry, ECB Working paper 758,

Commander; Simon and Jan Svejnar (2008): Do Institutions, Ownership,

Djankov S., R. La Porta, F. Lopez-De-Silanes, and A. Shleifer (2000) "The Regulation of Entry", NBER Working Paper 7892

Djankov, Simeon, Caralee McLiesh, Rita Ramalho (2006): Regulation and Growth, The World Bank, March 17

Dollar, David; Mary Hallward-Driemeier, and Taye Mengistae (2003): Investment Climate and Firm Performance in Developing Economies Development Research Group, World Bank November 2003

Economist (2010): The Economist, Vol. 397, № 8707

Eiffert, Benn (2007): The economic Response to Regulatory Reform 2003-2006. Paper commissioned by the Center for Global Development, Washington, University of California

Eiffert, Benn, Alan Gelb, Vijaya Ramachandran: Business Environment and Comparative Advantage in Africa: Evidence from the Investment Climate Data; in: Bougignon, F. and P. Blescovic, 2006, p.195-233)): Growth and Integration. Annual World Bank Conference on Development Economics, 2006

Exporting and Competition Explain Firm Performance? IPC Working Paper Series No 65, University of Michigan

FIAS (2009): Rat's Nest: How big is a rat's nest? The challenge of M\&E for Business Operations - a comparison of survey data and the "standard cost model" to measure the burden of licenses and permits for businesses. FIAS. The Investment Climate Advisory Service,World Bank/ IFC/MIGA

Gershenson, Dmitry (2010): Rwanda's Priority: Mobilize Resources for Massive Investment, IMF Survey, 21 December 2010 
IEG (2008): Doing Business:An Independent Evaluation. Taking the Measure of the World Bank-IFC Doing Business Indicators, Independent Evaluation Group, The World Bank Group, Washington

ICAS (2010): Here is your money. Using the standard cost model to measure regulatory compliance costs in developing countries. ICAS Investment Climate Advisory Service, The World Bank Group, Washington

La Porta, Rafael, Florencio Lopez-de-Silanes, and Andrei Shleifer (2008): Economic Consequences of Legal Origins, Journal of Economic Literature 2008, $46: 2,285-332$

Ministry of Trade and Industry (2009): Private Sector Cluster, Joint Sector Review Report, January - June 2009, Kigali, October 2009

Ministry of Trade and Industry (2010): Private Sector Development 2009/ 2010 Joint Sector Review Report, September 2010

Riedel, Henrik (2009): International Methods for measuring regulatory cost v1.1, Bertelsmann Stiftung, Gütersloh

SBP (2008): Cutting the Cost of Red Tape, Main Report, SBP Johannesburg

Streeck, Wolfgang and Kathleen Thelen (2005): Beyond Continuity. Institutional change in advanced political economies. OUP, Oxford

UNCTAD (2010'): World Investment Report, Geneva 2010

UNCTAD (2010²): Country Fact Sheet Rwanda, World Investment Report, Geneva 2010

World Bank (2005): Country Policy and Institutional Assessments. 2005 Assessment Questionnaire, Washington

World Bank (2009): Doing Business Annual Report, Washington 2009

World Bank (2010): Doing Business Annual Report, Washington 2010

World Bank (2011): Doing Business Annual Report, Washington 2010 